\title{
Comments
}

\section{AUTOMATIC EXTINCTION OF CROSS-DEMANDS: COMPENSATIO FROM ROME TO CALIFORNIA}

A client tells the following story: his auto was struck from the rear by a department store delivery truck, and he incurred minor injuries. The circumstances indicate that the truck driver was negligent and that the department store will be liable. Having established this, the attorney's next inquiry should be: has the client a charge account with the store? For if so, he may withhold payments on his charge account to recompense him for his injuries and the damage to his car; his charge account bill is paid to that extent. This result is dictated by Section 440 of the California Code of Civil Procedure:

When cross-demands have existed between persons under such circumstances that, if one had brought an action against the other, a counterclaim could have been set up, the two demands shall be deemed compensated, so far as they equal each other, and neither can be deprived of the benefit thereof by the assignment or death of the other. ${ }^{1}$

One possible meaning of the statute, and that which California courts have given it, is that cross-demands are automatically extinguished: they need only coexist at a moment in time at which the counterclaim requirement of Code of Civil Procedure Section 438 is satisfied. When these conditions are met, section 440 operates, and the respective demands are "compensated"-paid, discharged, acquitted-to the amount of the lesser demand. This legal extinction of the claims takes place automatically, without the knowledge or agreement of the debtors. ${ }^{2}$

A striking recent example is King Brothers Productions, Inc. v. RKO Teleradio Pictures, Inc. ${ }^{3}$ King sued for breach of RKO's agreement to distribute King's motion pictures. RKO counterclaimed, alleging that the script for one of the pictures was the property of RKO and that King had "converted said script to its own use; the value of said script was in excess of Two hundred and fifty thousand dollars." The counterclaim was more than two years old; under Code of Civil Procedure section 339 it would ordinarily be barred. But on King's motion for partial

${ }^{1}$ Car. Code Crv. Proc. $\S 440$. The section was originally $\$ 48$ of the Civil Practice Act of 1851, Cal. Stats. ch. 5 (1851).

2 E.g., King Bros. Prods., Inc. v. RKO Teleradio Pictures, Inc., 208 F. Supp. 271 (S.D.N.X. 1962); Hauger v. Gates, 42 Cal. 2d 752, 269 P.2d 609 (1954); Jones v. Mortimer, 28 Cal. 2d 627, 170 P.2d 893 (1946); Pan Pacific Sash \& Door Co. v. Greendale Park, Inc., 166 Cal. App. 2d 652, 333 P.2d 802 (1958); Suntise Produce Co. v. Malovich, 101 Cal. App. 2d 520, 225 P.2d 973 (1950).

3208 F. Supp. 271 (S.D.N.X. 1962).

4 Id. at 273 . 
summary judgment, the court lield the claim admissible under California's construction of section 440.5 The two demands-that of King and that of RKO-subsisted together only for that instant of time-unknown to the parties and the court alike, when first they coexisted. In that increment of time, the demands were "compensated" to the amount they were equal, leaving no outstanding claim on which the statute of limitation could run. This compensation took place though both demands were unliquidated; neither the court nor the parties knew, when King's motion for partial summary judgment was denied, the extent to which the demands were paid. That could be known only later, after the court ruled on the validity and amount of the respective claims.

Automatic compensation as exemplified by King Brothers, an automatic extrajudicial extinction of cross-demands, may be contrasted with three other means of dealing with reciprocal claims. First, the German Civil Code $^{6}$ provides that if two parties are mutual debtors of liquidated sums, either party may address a declaration to the other that the claims are compensated: this is termed facultative or volitional compensation." Second, in American law, mutual debts may be extinguished extrajudicially by the accord of both debtors. ${ }^{8}$ Finally, there are judiciallyadministered ineans of extinguishing mutual claims presented by the respective parties: common law examples include setoff, recoupment and counterclaim. ${ }^{9}$

5 Id. at 278 .

6 BÜrgerLTCHES GeSETZBUCH $\$ 388$.

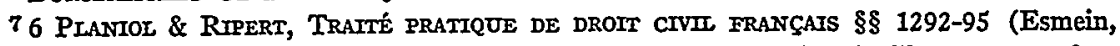
Radouant, Gabolde ed. 1954). For Planiol, facultative compensation is like common law accord and satisfaction, see note 8 infra, except that one party may invoke it. At French law, it does not operate retroactively.

8 The orthodox rule with respect to cross-demands is stated by Corbin: "The substituted performance accepted in satisfaction of a claim may itself be the discharge of some counterclaim; and nothing more is necessary to effectuate such mutual discharges than the agreement that they shall be so discharged. Such a transaction is not an accord executory; it is accord and satisfaction." 6 CORBIN, CoNTrACTs $\$ 1286$, at 157-58 (1962). The claims thus comprised can be unliquidated. Id. at 158. Accord, Restatearent, Contracts $\$ 422$ (1932). But if $A$ and $B$ are mutually indebted, and $A$ renders an account of their dealings, unreasonably long silence by $B$ is acceptance of the account. Ibid.

8 The definition and history of setoff are extensively treated in the text accompanying notes 163-76 infra. "Recoupment is contradistinguished from setoff in these three essential particulars: 1st. In being confined to matters arising out of, and connected with, the transaction or contract upon which the suit is brought; 2d. In having no regard whether or not such matter be liquidated or unliquidated; and 3d. That the judgment is not the subject of statutory regulation, but controlled by the rules of the common law." WATERMAN, Set-OFF, Recouparent and CoUnterclatm \$ 480 (2d ed. 1872).

Counterclaim, both the word itself and the first definition, is an invention of David Dudley Field. See text accompanying notes 194-200 infra. The current Code of Civil Procedure $\$ 438$, defining a counterclaim, differs markedly from the Field version, as a consequence of a 1927 amendment. Cal. Stats. ch. 813 (1927). See Clark, Code Pleadivg 
How did California law come to provide for automatic compensation in addition to counterclaim and cross-complaint? The rule of section 440 may be traced to Roman law, where the cancellation of cross-demands was known as compensatio. Twenty centuries later, section 440's progenitor was drafted by David Dudley Field, who was probably following a recommendation of Justice Story; Story had looked to Roman, French and English law.

This Comment returns to those sources. Part I discusses compensatio in the context of Roman civil procedure. Compensatio began as a judicial offset available in a narrow group of actions and concluded its Roman career as a broad counterclaim provision with some features of automatic compensation. Part II discusses the French law of compensatio. The north of France initially rejected it; the south readily borrowed it from the Romans. In borrowing, however, the "written law" of southern France interpreted Roman compensatio as providing for automatic extinction of cross-demands. While this interpretation was rejected by the Christian courts in France, it prevailed in the Code Napoleon; the Code and its authors had great influence upon David Dudley Field.

Part III discusses the influence of Mansfield and Story upon the law of setoff. Mansfield, learned in the Roman law, made the influential stateinent: "Natural equity says, that cross-demands should be compensated." Story, borrowing from the Romans and French, and from Mansfield, approved of the automatic extinction of cross-demands.

Part IV traces the legislative history of the current section 440, through David Field's Proposed Code of Civil Procedure, the Cahifornia Civil Practice Act of 1851, and the Code of Civil Procedure of 1872. Part V traces the California decisional law; no California case construmg section 440 has mentioned its civil law antecedents, and interpretations of section 440 have been diverse and, at times, quixotic. Part VI attempts to state a coherent view of section 440 , looking to its history and its potential effect upon the substantive and adjective law of cross-demands.

I

THE ROMAN ORIGINS ${ }^{11}$

Compensatio was devised as one means to abate the rigor which characterized pre-classic Roman procedural law. Parallehing reform in the

$\$ \S 100-01$ (2d ed. 1947); Comment, 1 U.C.L.A. L. Rev. 547, 564 (1954); Note, 31 CaLIr. L. REv. 210 (1943).

10 Green v. Farmer, 4 Burr. 2214, 2220, 98 Eng. Rep. 154, 157 (K.B. 1768).

11 This section draws heavily on background materinl in CARY, A HrstorX or ROME (2d ed. 1954); BOAK, A History of ROME to 565 A.D. (4th ed. 1955); TOUTAIn, TuE Economac LIFE of THE ANCIENT Wored (1951); the early chapters of Somar, TyE INstitutes: A Textbook of the History and System of Rojian Private Law (Ledlie 
means of creating obligations, ${ }^{12}$ Roman civil procedure strove in the fourth through the second centuries B.C. to discard the rituals involved in the enforcement of obligations and to adapt to the exigencies of an expanding commercial life. An early step toward reform was the creation of a new magistracy, the praetor, in 367 B.C. The praetor was invested with the power to publish, in a yearly edict, new causes of action which would be recognized in lis court. ${ }^{13}$ This reform in judicial administration left two major problems unresolved.

First, the forms of action-legis actiones-did not admit of counterclaim. The plaintiff stated his clain, the defendant responded according to the prescribed ritual, and the magistrate referred the case to a delegatejudge-a iudex-for decision. The referral, a grant of jurisdiction to liear and decide, directed that the iudex either find for the plaintiff or completely absolve the defendant. ${ }^{14}$ The procedure was in this sense reminiscent of the common law's fetish for reducing the lawsuit to one issue and turning the decision upon that issue. ${ }^{15}$

The other principal obstacle to orderly adjudication was the exclusion of aliens from the courts. A non-Roman was rightless, denied judicial enforcement of his contracts; this in a city with pretensions to become the commercial and political center of the Mediterranean. This condition was ameliorated piecemeal by a series of treaties granting Roman com-

transl. of 3d ed. 1907) [hereinafter cited as Somar] ; ROLI, A HISTORY OF ECONOMIC ThOJGHT 35-40 (3d ed. 1954).

12 One example of this rigor will suffice: mancipatio, the early ritual required to make a valid transfer of property. "[I]n the presence of not less than five Roman citizens of full age and also a sixth person, having the same qualifications, known as the libripens, to hold a bronze scale, the party who is taking by the mancipation, holding a bronze ingot, says: 'I declare this slave is mine by Quiritary right, and he be purchased to me with this bronze ingot and bronze scale.' He then strikes the scale with the ingot and gives it as a symbolic price to him from whom he is receiving by the mancipation. . . . The bronze ingot and scale are used because formerly only bronze money was in use; there were asses, double-asses, half- and quarter-asses, but neither gold nor silver money was current, as we may gather from the law of the Twelve Tables. The value of these pieces was reckoned not by counting but by weighing." Garus 1.119, .122 (de Zulueta transl. 1946). See BUCKIAND, A Mandal of Roman Private Law § 45 (2d ed. 1939) [hereinafter cited as Mandal]. With respect to Gaius, who wrote in the second century A.D., see, e.g., Somar $\S 18$, at 98; RADDN, ROMIAN LAW \& 31, at 81 (1927) [hereinafter cited as RADIN].

13 RADIN $\$ \S 8,14$.

14 GaTUS 4.11-.30 contains a discussion of the legis actio procedure, albeit in retrospect: the method had largely been abrogated by his day. See RADIN $\S 11$. The five legis actiones included a general one, one for attachment of the defendant's body, for attachment of his property, for appointunent of an arbitrator, and for the framing of a special issue. They were of broader scope than the common law writs; the rigor consisted in the faithfulness with which the ritual was executed and the single-minded pursuit of the utter condemnation or absolution of the defendant. "Condemn," in this connection, means to render a civil judgment sustaining the plaintiff's claim against the defendant.

15 See note 288 infra and accompanying text. 
mercial law rights to aliens. A more comprehensive solution was achieved in 243 B.C. with the appointment of the praetor peregrinus to hear cases in which aliens were parties. The former praetor took the title praetor urbanus. ${ }^{16}$ This reform betokened great changes in the whole of Roman substantive and adjective law. The urban praetor administered the Roman customary and statute law-the ius civile ${ }^{17}$ - much as before the appointment of the peregrine praetor. The peregrine praetor looked for guidance to the ius gentium, ${ }^{18}$ that body of rules common to the commercial practice of the polyglot community of bankers, traders, and businessmen who carried on Rome's foreign commerce. The existence of this dual legal system, rather hike the later coexistence of law and equity, ${ }^{19}$ led to subtle and pervasive changes in the ius civile. The ius civile, overtly and otherwise, borrowed from the ius gentium.

The peregrime praetor administered not only a more flexible substantive law; procedure before him was more informal as well. The plaintiff discussed his claim. The praetor, if he thought the allegations stated a claim within the ius gentium, set out written instructions on the disposition of the controversy-a "formula"20 and sent the matter to the delegatejudges who served his court. ${ }^{21}$ The formula also comprehended the de-

16 Somer $\S 13$, at $65-66$.

17 "That law which a people establishes for itself is peculiar to it, and is called ius civile as being the special law of the civitas. .." Garus 1.1. See Radin § 16; Somm § 11, at 48.

18 "[T]he law that natural reason establishes among all mankind is followed by all peoples alike, and is called ius gentium as being the law observed by all mankind." Garos 1.1. Law before the peregrine praetor was based on aequum et bonum-equity and justiceand upon customs of the known world. The available civil law rituals all contained the phrase "ex iure Quiritium"-deriving from my right as a member of a Roman clan-and were if only for that reason unsuitable. RADIN § 17 .

10 Matne, Anctent Law ch. 3 (1st ed. 1861).

20 The formula has no precise equivalent in American or English law; it was a grant of jurisdiction and statement of the case by the praetor, for the guidance of the iudex. It began with the appoimtment of the iudex. Then proceeded a statement of the case (the demonstratio), a statement of the issue (the intentio), then an instruction to condemn or acquit the defendant (condemnatio), or an instruction to adjust the conflicting claims of the parties (adiudicatio). Between the condemnatio or adiudicatio and the intentio might come pleas in avoidance or demial: the exceptio, replicatio, duplicatio, and so forth. Gaius has given us several examples of the formula, of which the following is one (Aulus Augerius, $A . A$.- the plaintifi-is Rome's John Doe; Numerius Negidius, $N . N$. - the defendant-is Richard Roe): $X$ is appoimted iudex. Demonstratio: Whereas Aulus Augerius sold the slave to Numerius Negidius. Intentio: if it appears that $N . N$. ought to pay A.A. 10,000 sesterces. Condemnatio: do thou, iudex, condemn $N . N$. to pay $A . A$. in 10,000 sesterces. If it does not appear, absolve. GaIos 4.39-.52.

The formula operated something like the common law writ plus the pleas which followed, but it had the advantage of being a formal reduction of a conversation between plaintiff and defendant about their dispute, in which all pleas were put in at once, rather than over months of procedural delay.

The formula was later replaced by the more complex cognition procedure. RADrN $\S 32$. 21 RADIN \& 17. 
fendant's pleas in bar of the plaintiff's allegations. Certainly before the delegate-judge, and perhaps in the formula as well, the defendant was also allowed to plead a sort of counterclain: compensatio. When the formula was adopted in the urban praetor's court in 150 B.C., this procedure was probably adopted as well. ${ }^{22}$

The source of compensatio is not known: Aristotle debates the merits of setoff in the Politics, but makes clear that no such procedure was used in the Athenian courts of his day. ${ }^{23}$ At its Roman inception, compensatio was available only when contracts of a certain type were sued upon. At an early date, Roman contract law had bifurcated into contracts stricti iuris and those bonae fidei, roughly corresponding to the division between unilateral and bilateral contracts. ${ }^{24}$ The most important contract bonae fide $i$ was that of sale-emptio venditio. ${ }^{25}$ The remedy for breach of this bilateral contract was by iudicium bonae fidei, a "good faith action." The distinctive feature of all such actions was that judgment was given for that amount which just men would say the defendant ought to pay. ${ }^{28}$ The defendant might raise objection before the iudex that he should not be required to pay the full price because, for example, the goods were shoddy. Other objections arising from the same bilateral transaction as that sued upon might also be raised before the iudex; it was not necessary that they be pleaded before the praetor or compassed in the formula: This offset, demanded by the defendant as a matter of good faith, marked the extent of compensatio at its origins.

Gaius' Institutes, written about 150 A.D., contain the earliest surviving discussion of compensatio: ${ }^{27}$

61. In bonae fidei actions the iudex appears to be allowed complete discretion in assessing, on the basis of justice and equity, how much ought to be made good (restitui) to the plaintiff, and this involves that he may take into account any counter-obligation due from the plaintiff

22 This change was wrought by the Aebutian law. RADIN \$ 18; GaIUs 4.30.

23 Aristotle says that "a qualified verdict [i.e., one taking account of and adjudicating a counterclaim] is possible in a court of arbitration, even where there are several arbitrators (for they can confer with one another in order to determine their verdict); but in a court of law such a verdict is impossible, since . . . the majority of legal codes contain specific measures that the judges shall not communicate." 2 ARIsTotre, Poirmics ch. $8, \S 13$ (Barker transl. 1946). Compare 4 BEAUCHET, HISTOIRE DU DROIT PRIVÉ DE LA REPUBLIQUE ATHENIENE 513-14 (1897).

24 BucrLand \& MCNatr, Roman Law and Common Law 271-76 (2d ed. 1952) draws the distinction and discusses the role of the unilateral binding promise in Roman law. See also BUCRLAND, A TEXT-BOok of ROMaN LAW § 153, at 437 (2d ed. 1932) [hereinafter cited as TexT-Book].

25 MaNUat §§ 107-08.

20 RADIN § 64, at 192-93.

$27 \mathrm{~A}$ portion of the text is missing, and the quoted section begins in the middle of Gaius' treatment of compensatio. 
under the same transaction and may condemn the defendant only in the difference.

62. The bonae fidei actions are those on sale, hiring, unauthorized agency, mandate, deposit, fiducia, partnership, tutorship, and wife's dowry.

63. It is nevertheless open to the iudex (in such actions) to take no account of any counter-obligation; for this is not enjoined expressly by the formula, but is considered to lie within his office as being consonant with a bonae fidei action. ${ }^{28}$

Gaius goes on to discuss invocation of compensatio against a banker; while regulated by different principles, the use of compensatio in that context may have presaged its expansion in later law. Bankers kept the accounts of Rome, and their records were of the greatest importance. If a banker sued, he was required to take account in his claim of all things of the same kind (and perhaps quality) which he owed the defendant. Should he fail to balance his books in the allegation and claim the sliglitest bit over, he was out of court. ${ }^{29}$ This was a special instance of the general rule that to be plus petitio - to have over-alleged-lost the action..$^{30}$

As Rome's financial life increased in complexity, the legal and political order clianged correspondingly. ${ }^{31}$ As Rome expanded by conquest and trade, available capital to support public works, private investment, and the immense military was expanded by means of paper stock certificates, bills of exchange, and related devices. ${ }^{32}$ Like the Roman legal system as a whole, compensatio was shaped to meet new needs.

Emperor Antomus Pius (138-161 A.D.) held that a private defendant could compensate claims against a governmental plaintiff, provided "the same department which is indebted is the plaintiff." 3 3 This ruling lias added significance when one considers the extensive financial dealings between the Roman state and the Roman men of wealth. ${ }^{34}$

It was Emperor Marcus Aurelius (161-180 A.D.), however, who

28 GaTUS 4.61-.63.

29 GATOS 4.64-.68.

30 GaTuS 4.53. The defendant might raise a claim of, for example, fraud, before the praetor, which was given effect by inserting an exceptio into the formula. If the cxceptio were proven, that meant the plaintiff had over-alleged; the transaction sued upon was voided and he lost altogether. There was thus an impetus for the plaintiff to "compensate" on his own before bringing the lawsuit, and to ask that the condemnatio be framed to give him the difference between his claim and that of the defendant. SorM \$ 89, at 442 . ManUaL \& 168, at 404-05.

31 Weber, From MaX Weber: Essays IN SOctology 166-67 (Gerth and Mills eds. 1946); Roll, op. cit. supra note 11, at 36 ; Toutain, op. cit. supra note 11, at 230-31, 246-59.

32 TotTats, op. cit. supra note 11, at 248; CaRy, op. cit. supra note 11, at 262.

33 CODE 4.31.1.

34 WEBER, op. cit. supra note 31 , at 167 . 
ordained the first important extension of compensatio: he ruled that compensatio was available in iudiciis stricti iuris - the form of action to enforce unilateral contracts-provided the defendant pleaded his claim by inserting an exceptio doli in the formula. ${ }^{35}$ This reform was doubly significant. First, since most of the contracts enforceable by an action stricti iuris were unilateral, Marcus's rescript apparently allowed compensatio when the claims arose from different transactions. ${ }^{36}$ Second, Marcus's order expanded the function of the exceptio in Roman pleading. Theretofore, an exceptio doli was pleaded by the defendant in bar of the plaintiff's claim; were it proven, judgment was given for the defendant "by way of exception." But an exceptio doli pleading compensatio was imserted to determine, not whether the defendant should pay the plaintiff, but how much he should pay. ${ }^{37}$

Given these reforms, how did compensatio operate? In other words, when the defendant pleaded compensatio, did the Romans regard the plea as submission of a countervailing claim for judicial disposition? Or was a plea of compensatio regarded as the allegation of the fact of countervailing obligations which had, automatically at the moment they first coexisted, mutually extinguished one another? In the former case, compensatio could only operate prospectively from the time of judgment; in the latter case, a judicial declaration that compensatio had taken place would be recognition of an existing state of affairs.

Scholars of Roman law disagree as to which view of compensatio prevailed in Rome. Sohm says that Roman law opted for a form of automatic compensatio "and expressed the view it adopted in the rule: ipso iure compensari."38 But he observes that the compensatio was provisional only, subject to be negated by, for example, advancement of a different claim at the time of suit, or by payment of one of the claims.

Buckland says that the defendant did not have to raise compensating claims in the plaimtiff's action, but could wait until later without having res judicata pleaded against him. ${ }^{39}$ Upon this, in part, he rests his view that ipso iure compensari did not mean automatic compensation. ${ }^{40}$

35 Marcus' declaration does not survive, but Justinian cites it at INsTrrutes 4.6 .30 (Addy \& Walker transl.). For a discussion of Justinian's codification, see RADIN $\S 34$; MANUAL \& 8, at 22-24. The function of an exceptio is discussed in text accompanying note 37 infra. "Doli" is a variation of "dolus," meaning any of a gamut of things ranging from guile to acts or omissions which do harm irrespective of the good or bad intent of the doer. See Black, Law Dicrionary 570 (4th ed. 1951).

36 See material cited at note 24 supra.

37 Sorem \& 89, at 443 .

38 Id. at 445. See generally UBbEHOLDE, IPso IURE COMPENSATUR (1858), which discusses the Roman texts in detail.

39 TEXT-Boor \& 238, at 705.

40 Ipso iure may be variously translated as meaning that compensatio takes places auto- 
Appleton, a French historian writing at the close of the nineteenth century, ${ }^{41}$ questions the innovating character of Marcus's rescript. $\mathrm{He}$ takes the view that the Roman provisions for stay of execution on the plaintiff's judgment, pending decision of a contemporaneous action brought by the defendant, would be meaningless if the defendant could raise all his claims in the plaintiff's lawsuit. Appleton's view is that Marcus himited the types of claims that could be compensated in the saine action. If the defendant's claim was other than incontestable and in the same coin as the plaintiff's, he had first to reduce it to judgment; the judge in the original action would then declare the compensation and the plaimtiff could execute on the difference. ${ }^{42}$

Of course, Sohin, Buckland, and Appleton could only speculate, for evidence of compensatio in the period after Marcus is limited almost entirely to that handed on by Justinian's compilers. In the codification of Justinian, later termed the Corpus Iuris Civilis, compensatio is treated in the Institutes, the Code, and the Digest. ${ }^{43}$

Sohn's view that coinpensation was automatic finds some support in a rescript of Emperor Alexander (221-235 A.D.) set forth in the Code; Alexander held that when two persons are inutually indebted to the same amount, compensatio operates ipso iure, and "takes the place of payment." In such a situation, interest is allowed only on "the surplus of the debt, which could not be extinguished by compensatio."

The Digest is nore explicit, and cites Ulpian:"5 "When one person owes another a debt without interest, and this other owes the first a debt with interest, following an order of Emperor Severus, interest is not due on the respective amounts. ${ }^{346}$ This seems to say that compensatio operated automatically to extinguish the claims, at the moment they coexisted and to the aniount of the lesser debt. But Appleton questions this construction of Ulpian's words. ${ }^{47}$ Ulpian may have been talkming only of certain types of debts. For example, a trustee is late in performance and therefore owes

matically, or that it takes place as of right when pleaded, or that it need not be pleaded in order to take advantage of it at trial.

.41 HISTOIRE DE IA COMPENSATION EN DROTT ROMAAIN (1895) [hereinafter cited as APPLETON]. Appleton was professor of law at Lyons.

42 See Id. ch. 5.

43 The Code collected decrees of the Roman emperors; the Digest was composed of excerpts from the work of Roman jurists; the Institutes was a treatise on Roman law, designed primarily for students. After the codification, later decrees were collected in the Novels. See Radin § 34; Manual \& 8, at 22-24.

44 Code 4.31.4. But see Appleton 470.

45 Ulpian, who served in important posts under Alexander Severus (222-35 A.D.), wrote at great length and with attention to system and detail. A third of the Digest is taken from his work. RADIN $\S 31$, at 82 .

48 DIGEST 6.2.11.

47 Appleton 290 n.1. 
interest: ${ }^{48}$ if it eventuated at the lawsuit that the cestui owed the trustee some money on another, interest-free, transaction, it would hardly be fair to charge the penalty-payment against the trustee. Appleton propounds other hypotheticals in arguing that it is just as logical, and more consistent with known Roman procedure, to think that the adjustment of interest reflected not an unseen hand adding figures in the ledger in the sky, but the iudex meting out practical justice. ${ }^{49}$

Another Digest fragment says that obligations which could not be the basis of a lawsuit in the first instance might be set up by way of compensatio when defending a suit. .0 These "natural obligations" were consensual agreements barred by a specific incapacity or defense, such as minority, on the part of one or both of the parties. ${ }^{51}$ The nature of natural obligations was essentially equitable, and enforcement ordinarily left to a sense of honor. But, if one party performed, though he had no legal obligation to do so, he could not sue and get back what he had given. ${ }^{52}$

As unexecuted natural obligation could, if Ulpian is correctly quoted in the Digest, "be set up by way of compensatio." words is that when the plaintiff sought to change the status quo by suing on a contract which fulfilled the technical requisites for validity, the defendant could ask that money due him under a contract invalid for technical reasons be put into compensation against the plaintiff's demand: he who claims justice must do justice. Buckland, lowever, is of the view that the pacts of a slave were the only natural obligations which could be set up in compensatio. ${ }^{54}$ Appleton quotes Ulpian's comment and notes that most of the surviving fragments of this section of Ulpian's work deal with partnership. ${ }^{55} \mathrm{He}$ concludes that "it is with respect to a genuinely bilateral contract, that of partnership," that Ulpian made the quoted observation. " "The compliers ..." says Appleton, "in isolating the fragment from its context, gave it a general siguificance which it did not have; the possibility of setting off in compensation natural obligations has to be restricted to claims arising from the same transaction." $" 57$

48 GaIUS 2.280 .

40 Hart \& Sacks, The Legar Process 132-34 (tentative ed. 1958), distinguishing "selfapplying" from "individually-administered" regulations, suggests the difference.

50 Digest 16.2.6.

51 RADIN § 112a; SOHM § 84, at 414; MaNUar § 133.

62 The closest analogy at common law is to an executed gift: if $A$ promises to make a gift to $B$ in 5 days, there is no enforceable contract. But if $A$ delivers the gift, a court will not let him get it back. See, e.g., Gray v. Barton, 55 N.Y. 68 (1873).

53 DigesT 16.2.6.

54 Manual $\$ 133$, at 337 .

65 APPLETGN 66-68.

$56 I d$. at 67 .

67 Ibid. Appleton discusses a case involving a slave's bilateral contract, and concludes compensatio was not involved. Id. at 67 n.3. 
Whatever the status of compensatio after Marcus, it is certain that Justinian introduced changes. Appleton believes the changes were designed to rectify injustices resulting from a defendant's ability to upset the action at any stage with a fraudulent counterclaim; ${ }^{58}$ the more usual view is that Justinian broadened compensatio. ${ }^{59}$ Justinian himself says that "a constitution of ours has more widely introduced those setoffs [compensationes] which rest upon manifest justice." ${ }^{100}$ The constitution to which Justinian refers is set out in the Code:

We order that compensatio takes place as of right [ipso iure] in all actions, real or personal.

$\S .1$. We allow compensatio when the credit offered in payment is liquid [liquida], does not raise difficulties, and is susceptible of being easily adjudicated; for it is unjust that when a case has been proven after much discussion, the other party, who is almost convicted, can plead compensatio against an ascertained and unmistakable debt, and defeat expectations by protracting the proceeding. Hence, we recommend that judges not lightly or with indifference admit compensatio, but proceed strictly; and should it appear that the proposed compensatio would require great and lengthy inquiry, we order that such a claim be saved for another action, and the former inquiry, almost entirely concluded, go to judgment. We except from the actions in which compensatio is available, the action of deposit. . . . ${ }^{61}$

\section{§.2. Neither may an adverse possessor set up compensatio. ${ }^{22}$}

The Roman treatment of compensatio, from its beginnings in the formulary procedure to Justinian's Corpus Iuris, influenced common law treatment of cross-demands in two major ways. First, the direct influence of the Corpus Iuris upon common law scholars such as Story and Mansfield is acknowledged. ${ }^{63}$ Second, Roman law principles were adopted and adapted in Continental Europe by secular and ecclesiastical tribunals; this Continental law-principally, in the case of compensatio, that of France-was itself influential in the work of common law judges and scholars. The work of Story and Mansfield is considered in part III of this Comment; part II discusses the assimilation of Roman compensatio into the legal system of France.

58 Id. at $409-11$.

59 E.g., SoEM \& 89, at 445-46.

60 INSTITUTES 4.6.30.

61 InSTITUTes 4.6 .30 notes that it would be unfair to allow a setoff when the plaintiff seeks restitution of a specific chattel. Further, the fiduciary nature of the deposit agreement precluded other than faithful performance of the agreement notwithstanding crossdemands.

62 Code 4.31.14.

${ }^{63}$ See notes 160, 177-88 infra and accompanying text. 


\section{II \\ compensatio IN FRENCH LAW}

Though the Roman origins of compensatio were recognized by eighteenth and nineteenth century legal scholars, most of them looked first to the French interpretations of the doctrine for guidance. The French students of Roman law had unfortunately achieved an imperfect view of Ronian compensatio, arising in part from inconiplete information, and in part from their respective political biases. Compensatio, and related forms of setoff and counterclaim, created heated pohtical controversy in nedieval France, and the ultimate French view of compensatio in the Code Napoleon is a synthesis reflecting conflicting demands for national unity and local feudal privilege.

After the thirteenth century, France was split into two fairly distinct areas. In the northern two-thirds of the country, the customary law ${ }^{64}$ governed: each feudal fiefdom had its peculiar admixture of rules descended from the barbarian invaders, nuore or less modified by Roman and canon influences. To the south, the medieval period saw the flourishing of "written law" based upon Justinian, whose work had beconre the focus of scholarly study. ${ }^{65}$ The canon law comprised a third legal system, uniforn throughout France. Based in its secular aspects upon Roman law, canon law influenced the secular courts, and was applied directly to cases within the jurisdiction of the Christian courts. ${ }^{68}$ The view of compensatio differed in each of these three legal systems.

\section{A. The Customary Law}

Those who overturned Rome's control of Gaul estabhshed the "personality of laws": one called to court was held by the law of his own people. ${ }^{67}$ In the barbarian kingdoms of Gaul-Burgundian, Visigoth, and Frankish-jural relations between Ronian and Roman were governed by Roman law; those between a Roman and one of the dominant tribe were probably governed by barbarian law. In time, however, this system faced two difficulties. First, imtermarriage made inquiries about origins somewhat artificial. Second, "judges had to be capable of knowing and understanding the texts of the various Laws and royal anendments; instead, ignorance and barbarity increased constantly . . . and a well-read man

64 "Customary" denotes that the legal rules were based upon usage and tradition, rather than on statute.

65 ESMIET, CoURS ELEMENTAIRE D'HISTOIRE DU DROIT FRANÇAIS 786-87 (11th ed. 1912) [hereinafter cited as EsMEnN].

60 ESMIEIN 862-64.

67 Esaremn 57-64, 782-83; 1 Lanne, Drolt international PRvé 60-66 (1888). 
became a rarity." ${ }^{\text {8s }}$ As a result, the concept of "personality of law" came to be repudiated, and in each region there was formed a customary law uniformly applicable to all those domiciled there. Naturally, in each area the laws of the dominant race furnished the principal constituents of the customary law. ${ }^{69}$ Each feudal fiefdom came to have its own set of laws.

Canon and Roman law exerted great influence upon the customary law; acceptance of canon and Roman principles by customary law courts had far advanced by the time of Louis XIV. ${ }^{70}$ Illustrative is the initial rejection and later acceptance of judicial offset and automatic compensation. An early reliable record ${ }^{71}$ is a treatise on the customary law of Beauvaisis, completed in 1283 by Philippe de Beaumanoir. ${ }^{72}$ Beaumanoir notes that counterclaims were allowed by the courts Christian. In the seigneurial, or lay, courts a defendant could only defend, and could not raise a cross-demand. ${ }^{73}$ The defendant was not limited, however, to either confessing or denying that he had indeed incurred the obligation. He could plead "payment," a term embracing defenses which a modern court would denominate counterclaim. Beaumanoir propounds a case in which a cleric is suing for twenty pounds due him from a layman. The layman says that with the intention of discharging the debt, he lent some money to the cleric. The cleric replies that the court should make the defendant pay up; if le wants the money le lent, he should make a claim to the cleric's monastic seigneur. But he cannot thus escape.

We before whom these pleas are contested say to the cleric that if he does not respond to the layman's plea that he has lent the cleric something after the debt of twenty pounds was incurred, we will not constrain the layman to pay the twenty pounds, for he was not making a counterclaim when he said that he had lent the money with the intention of discharging the debt; but if he demands of the cleric something due at a time before the debt was made, or he demands

68 ESMEIN 782.

$69 \mathrm{Id}$. at $782-83$.

70 The canon law treatment of cross-demands is discussed in text accompanying notes 119-31 infra.

71 The reliability of Beaumanoir is attested by, inter alia, EsMrex 800-01.

72 Beaumanotr, Coutumes de Beauvatsis (Salmon ed. 1899).

73 Id. § 357: "There is a custom in the Christian court which is not observed in the secular court: for if Peter demands ten pounds that John has contracted to pay him, John can demand of Peter that he return a horse which he has provided to him. . . . And this custom is called counterclaim by the Christian court. And if the said Peter who has sued the said John does not want to respond to the claim for the horse because he was not summoned to respond to John as John was summoned to respond to him, then John need not reply to the claim for the ten pounds. But it is otherwise in the secular court, for he who is summoned must defend, and the defendant cannot make a demand without a separate summons for any claim other than that to which he was called to answer. . . Thus one can see that counterclaims do not arise in the secular court as they do in the Christian court." 
of him horses, or other beasts, or grain, or wine, or other things having no connection with the twenty pounds, we will oblige him to pay the twenty pounds and make his claim before the cleric's ordinary. ${ }^{74}$

Beaumanoir's discussion does not even consider automatic extinction of cross-demands; he is concerned only with the scope of judicial offset; the claims which a judge will cognize in adjusting cross-demands as of the time of the suit. It is reconventio-counterclaim-not compensatio.

Somewhat later, other customary law jurisdictions considered both concepts, and rejected both. When the customary law of Lorris and Montargis was put in writing in 1531, it was flatly stated:

IX. Counterclaim takes place not at all in the secular court.

$\mathrm{X}$. Compensation [of cross-demands] takes place not at all in the secular court. ${ }^{75}$

Loisel, summarizing the customary law in $1608,{ }^{76}$ was equally explicit:

$\S .704$. One debt prevents not at all the existence of another. . . In a word, this means that where there are mutual and reciprocal debts, each of the parties must tender payment of that which is due, neither being able to counterclaim or compensate. ${ }^{77}$

Hence, compensation and counterclaim were known to the customary law. A major obstacle to their acceptance, however, seems to have been jurisdictional covetousness. This state of affairs rested upon two considerations. First, seigneurs refused to tolerate usurpation of their local jurisdiction by outsiders. If Peter went before John's lord to present a claim against John, Peter and his lord were not disposed to submit to the indignity of John's lord adjudicating a claim against Peter. Second, not until the seventeenth and eighteenth centuries did Roman law experience the rebirth of influence that promoted acceptance of compensatio and counterclaim by the customary law. ${ }^{78}$

The view that feudal jealousy and insularity were chiefly responsible

$74 I d . \S 359$.

75 Les coutunzes anciennes de Lorris, des bailliage et prevosté de Montargis ch. 21, arts. 9-10 (1531), in 3 NoUvead CoUTUMTIER GENERAI 829 (1724) [the collection is hereinafter cited as N.C.G.]. The citations to N.C.G. in this Comment are in the following form: first the title of the code of customary law, followed by the place in that code referred to im the text, followed by the date, if available of the codification. The citation to N.C.G. follows, with volume number and the number of the page in that volume on which the reprint of the particular code begins.

76 LoISer, INSTITUTES COUTUMmères (Dupin \& Laboulaye ed. 1846). The original publication date was 1608. ESMEIN 814.

77 LoIser, op. cit. supra note 76, at $\$ 704$.

78 On the influence of Roman law, see generally Esarem 782-846; 1 SHERMaAN, RoMaN LAW IN THE MODERN WORLD \$ 241 (3d ed. 1937); VINOGRADOFF, ROMAAN LAW IN MEDIEVAT EURope 65-83 (1909). Assimilation of the Roman principles of compensatio is discussed in text accompanying notes 83-118 infra. 
for the customary law's refusal to cognize counterclaims is suggested by representative, though far from complete, evidence drawn principally from the officially-sanctioned expositions of customary law. ${ }^{70}$ The monarchy encouraged reducing the customary law to writing in this manner as an attempt to introduce consistency and clarity in the law. ${ }^{80}$

A writer upon the custom of Meaux in 1683 cited two reasons for not allowing judicial offset in the secular court. First, the plaintiff was ordinarily required to sue the defendant in the latter's jurisdiction. Second, the maintenance of the system of feudal justice, with obligations and rights inherited by lord and vassal alike, required that adjudications of property rights originating in Meaux not be subject to divestment in, for example, Lorris. ${ }^{81}$ The Coutume of the Marche in 1521 incorporated this concept into its definition of judicial offset: "Counterclaim takes place not at all, unless the parties be domiciliaries of the same forum, in which case it takes place without a new action." 82

In the late sixteenth century, the provincial view evidenced by these rules began to give way. Roman law was an influence; when it came time to reduce the custom to writing, some gaps might be filled by reference to Justinian..$^{83}$ Perhaps, too, experience had shown that counterclaim could be tolerated; when admitted by special dispensation, ${ }^{84}$ the anti-

70 The NoUveaU CoUTuMAIER GeNeral (1724) is an authoritative collection, reproducing with notes by jurists the local collections of customary law; citcd hercin as N.C.G., it is the collection in which the original research for this Comment was done. On the reduction to writing of the customary law, see EsMEnN 815-32; SHERMan, op. cit. supra note 78 , at $\$ 240$.

80 ESMEn 824 . When the law was written down and available for study, criticism by legal scholars prompted many fiefdoms to redraft. Ibid.

81 BobÉ, CoMmentatre sUR IES COUTUMAes generales de MeaUX 444 (1683), discussing Coutumes generales gardées et observées au bailliage de Meaux art. 219 (1509), in 3 N.C.G. 381. See also the emphasis on jurisdiction in BEAUMANOR, op. cit. supra note 72, at $\$ \S 357-60$. The jurisdictional objection to a free right of counterclaim is squarely raised in a contemporary comment upon the customary law of Paris: FERruerre, Corps ET COMPIIATION DE TOUS IES COMMMENTATEURS ANCIENS ET MIODERNS SUR IA COUTUME DE PARIS 105-06 (2d ed. 1724). Other contemporary statements include Coustumes generales du pays et duché de Bourbonnois (1521), in 3 N.C.G. 1231, at 1289; Coutumes de la prevosté et vicomté de Paris (1580), in 3 N.C.G. 29, at 38 n.2; BourJon, LE DroIT COMOMUn DE IA France bk. 6, tit. 7, ch. 2, §§ 32-33 (3d ed. 1770) notes that counterclaims are not allowed 'in the secular court, while compensatio may be: hence, only liquidated demands may be compensated. The consequence of allowing compensation of unhquidated demands would be to allow by compensatio that which could not be achieved by counterclaim. Furtler, as to jürisdiction, see generally EsMrens 293-301.

82 Coutumes generales du haut pay du comte de la Marche $\S 101$ (1521), in 4 N.C.G. 1101.

ik 83 ESMETN 790-92.

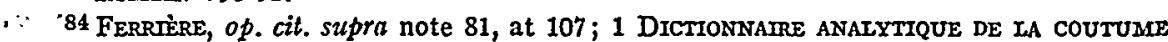
DE Noracande 314 (1780); 3 N.C.G. 145 n.n, commenting upon Coutumes du comté et baillages de Montfort Lamaury $\S 69$ (1556), in 3 N.C.G. 141. 
cipated pernicious consequences may not have appeared. Further, royal pressures for uniform law apparently played a major role.

Adoption of a limited counterclaim by the customary law of Paris exemplified the change. The 1510 Coutume had flatly stated that "Counterclaim, in the lay court, takes place not at all..885 But the 1580 version read: "A counterclaim in the secular court is not admissible unless it relates to the subject of the action, and the demand in counterclaim be a defense to the action flrst instituted; in this case the defendant, by means of his defense, may make himself plaintiff." Commentators upon this provision made it explicit that the demands must be so connected that one might say they were part of the same action. Otherwise, the defendant must seek the plaintiff in the forum of the latter's domicile. ${ }^{87}$

The Paris provision bespoke a trend: many other principahties, duchies, and fiefdoms allowed judicial offset by the latter half of the sixteenth century. ${ }^{88}$ In 1683, however, Bobé noted that the custom of Meaux had not followed Paris in allowing counterclaim; he suggested that the Parisian provision "ought to be incorporated into the Custom of Meaux." 89

Contrast, however, the treatment of compensatio with that of counterclaim. The provincial quibbles which impeded acceptance of counterclaim did not apply with equal force to automatic extinction of reciprocal debts. To allow compensatio fell short of requiring a defendant to surrender tangible property at the behest of a judge in a foreign forum..$^{90}$ Compensatio could, at most, reduce a plaintiff's claim to zero. In no event could a plea of compensatio lead to an adjudication that legal relations sanctioned by one lord were to be undone in the forum of another lord. ${ }^{91}$

85 Les Coutunnes generales due la prevosté et vicomté de Paris $\S 75$ (1510), in 3 N.C.G. 1; FERRIÉre, op. cit. supra note 81, at 103-04.

86 Coutumes de la prevosté et vicomté de Paris $\$ 106$ (1580), in 3 N.C.G. 29; Ferrière, op. cil. supra note 81, at 103-04.

87 FERRIERE, op. cit. supra note 81, at 103-04.

88 E.g., Le coutumier du bailliage de Mante art. 1, § 3 (n.d.), in 3 N.C.G. 173; Coutumes du comté et bailliage de Mante et Meullant $\$ 58$ (1556), in 3 N.C.G. 183; Coutumes du bailliage de Meleun $\S 327$ (1560), in N.C.G. 434; Coutumes du comté et bailliages de Montfort Lamaury $\$ 69$ (1556), in 3 N.C.G. 141 (requiring special dispensation); Coutumes generales de la cité et duché de Cambray tit. 25, §§ 52-53 (1574), in 2 N.C.G. 281; Coutumes de la ville de Calais et pays reconquis § 223 (1583), in 1 N.C.G. 1.

89 BobE, NOTES SUR IA COUTURE DE PARTS 73 (1683), bound with the same author's

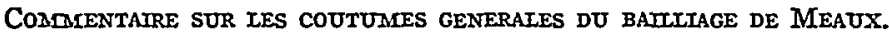

90 This "great difference" appeared clearly to the authors of comments collected in Ferrtire, op. cit. supra note 81, at 108.

01 The question of jurisdiction to render a personal judgment raises analogous problems in the Umited States today. If $A$ seeks $B$ in the forum of $B$ 's domicile, and $B$ counterclaims for an amount in excess of $A$ 's claim, the court in $B$ 's domicile is not constitutionally barred from granting $B$ all the relief he seeks. Adam v. Saenger, 303 U.S. 59 (1938). Adam rests this decision upon $A$ 's "consent." This result could not obtain in medieval France. $A$ could 
While this minimized the jurisdictional impediment, the alien character of compensatio remained a barrier to its acceptance. But as royal power expanded, as the customs were reduced to writing, as French scholars revived the study of legal history, the Roman intruder came to be tolerated if not welcomed.

In 1531, the custom of Lorris and Montargis excluded compensatio from the secular court, ${ }^{92}$ as did Tournay in $1552 .^{93}$ There is no mention of compensatio in the Coutumes de Bourbonnois of $1500,{ }^{94}$ nor in that of Meaux of $1509,{ }^{95}$ nor in the old undated ${ }^{96}$ or $1556^{97}$ editions of the customary law of Mante. Neither is it mentioned in the Coutumier de Cambray of 1574, nor that of the Boulenois of 1550 . This may mean nothing: perhaps the custom was silent and the Roman principle employed. The collection of Norman customs does not mention compensatio, yet Basnage made it clear that the principle was cautiously received..$^{88}$

On the other hand, many sixteenth century collections of customary law exphicitly provided for automatic compensation to greater or lesser extent. $^{.9}$ In Paris, both the 1510 and the 1580 Coutumes allowed it if the debts were liquidated and incontestable. ${ }^{100}$ In Auvergne as of 1510, the debts had also to be in writing. ${ }^{101} \mathrm{By} \mathrm{1521}$, the Bourbon custom allowed compensation provided the defendant pleaded the opposing debt at the outset of plaintiff's action; the compiler of the custom declared that jurisdictional covetousness "cannot be allowed to impede the ad-

not consent, as his personal rights were very much bound up with his feudal relation to his own lord; $B$ 's lord could not adjudicate those rights, for to do so would invade the seigneurial privileges of $A$ 's lord. Today, tenurial rights are all but gone as viable legal constructs; $A$ 's property rights are his personally, and since he can dispose of them by a contract made in the forum of $B$ 's domicile, there is no reason not to let courts of that forum adjudicate them.

${ }^{02}$ Les coutumes anciennes de Lorris, des bailliage et prevosté de Montargis ch. 21, art. 10 (1531), in 3 N.C.G. 829.

${ }^{93}$ Les coustumes, stils, et usages de l'eschevinage de la ville et cité de Tournay ch. 27, art. 1-2 (1552), in 2 N.C.G. 951.

94 Coustumes du pays et duché de Bourbonnois (1500), in 3 N.C.G. 1193.

95 Coutumes generales gardées et observées au bailliage de Meaux (1509), in 3 N.C.G. 381. See BoBÉ, op. cit. supra note 89.

96 Le coutumier du bailliage de Mante (no date), in 3 N.C.G. 173.

97 Coutumes du comté et bailliage de Mante et Meullant (1556), in 3 N.C.G. 183.

981 BasNage, Oeuvres 88 (4th ed. 1778). Basnage believed that a debt not at interest could not compensate one at imterest. Ibid., citing duMoulin in support of his conclusion. After 1665 , lowever, the procedural formalities formerly prerequisite to judicial allowance of compensatio were done away with, 1 DICTIONNATRE ANALYTIQUE DE IA COUTUME DE NORMANDIE 314 (1780); this may liave broadened the operation of automatic contpensatio.

99 Brissaud, A History of French Private Law 558 n.2 (1912), attributes the French acceptance of automatic compensation to Cujas.

100 FERRike, op. cit. supra note 81 , at $87-88$, discussing art. 74 of the 1510 Coutumier and art. 105 of the 1580 version.

101 Les coutumes genterales du haut et bas pays d'Auvergne ch. 18, art. 6 (1510), in 4 N.C.G. 1160 . 
judication of the day to day transactions of the subjects of the realm."102 Similar rules were reduced to writing in Rheims, ${ }^{103}$ the Marche in $1521,{ }^{104}$ Meleun in $1560,{ }^{105}$ Montfort in $1556,{ }^{108}$ and Calais in $1583 .^{107}$.

Loisel, summarizing the customary law, wrote in 1608 that compensation required that "the debts one wishes to compensate be liquid and in writing." "108 This, he said, was "an exception, or rather an abrogation of the rule that a countervailing obligation does not prevent the existence of the principal demand." 109 Loisel's statement carries three connotations. First, the rule prohibiting compensatio was subject to attack, and had been put to rout in some jurisdictions. Second, the attack was in some cases guised as an exception to the former rule; as Sir Henry Maine noted, ${ }^{110}$ a new rule travelling incognito as an exception is a significant element in legal progress. Third, where it appeared, compensatio operated automatically to extinguish countervailing obligations; the customary law was moving toward the view of compensatio taken in the "written law" of southern France.

\section{B. The Written Law}

In the district of the droit ecrit, or "written law," Roman law formed the common and general law. Judges looked to Justinian for guidance. ${ }^{111}$ They were assisted by the revival of Roman law study and exposition which began in Bologna in the twelfth century: the Glossators' marginal notes, explaining, discussing and comparing the text in the scholastic manner, aimed "to re-establish the authority of Roman law as living law."112

The Glossators were succeeded by the Commentators; exegesis of Justinian's text gave way to long discussion of particular points, and exhaustive distinctions. ${ }^{113}$ The sixteenth century saw the growth of a humanist school of jurisprudence. Led by Cujas in France, the humanists

102 Coustumes generales $d u$ pay et duche de Bourbonnois $\S \S 37-38$ (1521), in 3 N.C.G. 1231. The quoted observation is in id. at 1289.

103 Coutumes de la cité et ville de Rheims art. 397 (no date), in 2 N.C.G. 493.

104 Coutumes generales du haut pay du comté de la Marche $\S 100$ (1521), in 4 N.C.G. 1101.

105 Coutumes du bailliage de Meleun $\S 326$ (1560), in 3 N.C.G. 434.

108 Coutumes du comté et bailliages de Montfort Lamaury $\$ 68$ (1556), in 3 N.C.G. 141. 107 Coutumes de la ville de Calais et pays reconquis $\$ 222$ (1583), in 1 N.C.G. 1.

108 LoISEL, op. cit. supra note 76 , at $\S 705$.

109 Ibid.

110 Manke, ANCIENT Law ch. 2 (1st ed. 1861).

111 ESMEEN 787. But customary anomalies developed in the South on matters left open by Roman law, principally the hierarchy of rights and duties inherent in feudal economic and jural relations. $I d$. at $787-88$.

112 Soms 138. And see VinogradofF, op. cit. supra note 78, at 44-58.

1131 ShrRaran, op. cit. supra note 78, at $\S 219$. 
returned to Roman law, to search out, clarify, and expound the thoughts of the Latin lawmakers. ${ }^{114}$

These influences molded the Corpus Iuris of Justinian into the day-today rules of a feudal society. The interpretation of compensatio by courts and scholars was later adopted by the Code Napoleon: Justinian's words "ipso iure" were construed to mean "by operation of law alone." this interpretation, compensation of cross-demands took place automatically without the knowledge of the debtors at the moment the two debts first coexisted, and to the amount of the lesser debt. ${ }^{118}$ Brissaud credits this interpretation to Cujas, ${ }^{117}$ but Cujas was not all alone. Pothier, writing in the eighteenth century, asserted that the lexicographers unanimously agreed that Justinian's words could bear no other meaning. 118

\section{The Canon Law 119 $^{119}$}

The ecclesiastical courts applied canon law to all matters within their jurisdiction. The Church pressed the secular courts to apply canon law principles as well, when it thought the welfare of men's souls was at issue. ${ }^{120}$ The canon law purported to be, therefore, both a system of positive law compassing the jural relations of an ecclesiastical society, and an exposition of the principles of divine law. In its positive aspects, it leaned heavily upon Roman law. ${ }^{121}$ In contrast with the French written

114 ESMEIN 843-44.

115 See note 40 supra.

116 DOMat, Les LoIx crVILES DANS IEUR ORDRE NATUREI 284 (1713). The cited edition is not the first; the title page speaks of it as "Nouvelle edition, reveuë et corigée." The work was published in segments from 1689 to 1697 , in part posthumously, Domat having died in 1695. Domat's authority and influence rest upon his view that Roman law contained "natural law and written reason," and upon his systematic exposition in French rather than in Latin. Realizing that the Roman law was entitled to, and accorded, great weight in the courts, he sought to make that law accessible. EsMEDN 845-46.

117 BRISSAUd, op. cit. supra note 99, at 558 n.2.

118 Pothier, Traité des obligations $\S 635$, in 2 Oeuves 1 (Bugnet ed. 1861) [the Traité is hereinafter cited as Pothier, then to the section, and, if necessary to the page of volume 2 of the Oeuvres where the cited inaterial appears]. The Traite, of great influence upon the codifiers, was originally published in 1761. 2 id. at ix. Pothier, as the discussion in part I of this Comment indicates, was probably wrong in thinking compensatio was automatic at Roman law.

Automatic compensation meant, for example, that without exception a debt bearing interest compensated and extinguished a debt not at interest. DoMAr, op. cit. supra note 116, at 284 .

Roman law did not, however, prescribe the details of the feudal relation: that was left to custom. In the written law of the south, as in the customary law of the north, feudal obligations were not susceptible of compensation. Id. at 285; Ferruère, op. cit. supra note 81, at 99-100.

110 See generally VINOGRADOFF, op. cit. supra note 78, at 68-83.

120 ESMEDN 862-64.

121 Hobbes, LeviathaN 457 (Oakeshott ed. 1957): "For if a man consider the original 
law insistence that Roman law provided for automatic extinction of crossdemands, the canonists allowed only judicial offset.

Cross-demands at canon law were heard before the same judge at the same time; he rendered a smgle judgment adjudicating the respective claims. ${ }^{122}$ The cross-demand could be pleaded at any time before joinder of issue, and had the effect of "making the plaintiff into a defendant before the same judge."123 The canonists called this form of cross-action mutuae petitiones-“mutual petitions." These words appear in Justinian's Code in the treatment of compensatio: "You cannot be constrained to pay that which you obviously owe, before there has been a response to your mutual petition against your creditor, whom you allege is also your debtor."124 Pothier records that these words of Justinian are the basis for a view among legal scholars that the demands coexist until set off by the judge. ${ }^{125}$ It is not unreasonable to suggest that the choice of the words "mutual petitions" to head the treatment of cross-demands in the Corpus Iuris Canonici, ${ }^{128}$ and in the canonist Institutes of Lancellotti, ${ }^{127}$ reflects insistence upon the procedural prerequisites to setoff.

In Hericourt's Les loix ecclesiastiques de France, ${ }^{128}$ the subject is treated under the head of "reciprocal demands"; without acknowledging his source, he repeats the material contained in the Corpus Iuris Canonici section on "nuutual petitions." Hericourt distinguishes the judicial offset dictated by the papal rescripts from the compensatio which would be available in the secular court. ${ }^{129}$

For the canonists, of course, jurisdictional difficulties attending crossdemands in the secular court did not exist: the law was uniform through-

of this great ecclesiastical dominion, he will easily perceive that the Papacy is no other than the ghost of the deceased Roman empire, sitting crowned upon the grave thereof. For so did the Papacy start up on a sudden out of the ruins of that heathen power." Theological polemic aside, the statement is accurate as respects the relation of Roman law to ecclesiastical temporal law.

122 Decretal. Gregor. IX bk. 2, tit. 4, ch. 1, in 2 CORPUS JuRIs CANONICI at cols. 256-57 (Friedberg ed. 1879).

1233 Lancexiotto, Institurtones Juris Canontci tit. 9, § 1 (1704). This work, commissioned by Pope Paul IV as the canonical counterpart of Justinian's Institutes, was first published in 1563; it never received papal approval, but is recognized as authoritative. 1 SHERMAN, op. cit. supra note 78, at § 228.

124 CODE 4.31.6.

125 Pothier \& 635, at 346.

126 Decretal. Gregor. $I X$ bk. 2, tit. 4, chs. 1-2, in 2 Corpus Jurus Canonict at cols. 256-57 (Friedberg ed. 1879).

1273 LANCEILOTTO, op. cit. supra note 123 , at tit. 9.

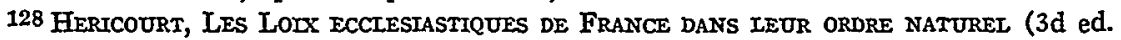
1771). The first edition was published in 1719.

120 Id. at D92. Pothier notes that the canonists held that a debt attested by an oath could not be discharged by compensatio because such a means of discharge would derogate from the letter of the promise. Pothier $\$ 625$, at 338 . 
out the church. Quite simply, the canonists thought it wrong that a man "decline to have against himself in the same action a judge whose decision he respects as plaintiff."130 The canon law was, however, assiduous to protect its own jurisdiction: a defendant sued in a secular court by a cleric could not counterclaim about a matter cognizable by the ecclesiastical courts. ${ }^{131}$

But the canonists' preference for judicial offset was eclipsed by those who argued that Justinian provided for automatic compensation. The words ipso iure, not mutuae petitiones, seemed most important to the architects of the Code Napoleon.

\section{The Codification of Compensatio}

The feudal jealousies reflected in the chill welcome received by compensatio were symptomatic of the struggle to unify France. Unification was a major concern of the monarchy front the sixteenth century on, and was pursued by reducing the customary law to writing under royal supervision, promulgation of royal decrees binding the whole kingdom, and assertion of the king's place at the top of the feudal pyramid. ${ }^{182}$ The new class of traders and merchants was likewise interested in breaking down barriers to commerce, and they pressed for unity-and political and economic freedom. ${ }^{133}$ Amid all, the philosophes of the Enlightenment sought and expounded the fundamental principles which ordered the universe. ${ }^{134}$ They proclaimed three truths to the lawgivers of the French Revolution: the law must be unified, certain, and derive its sanction from natural reason.

Unification built upon the work of Pothier and Domat, and upon the Coutumes-especially that of Paris. ${ }^{135}$ That certainty was an object is attested by the Declaration of Rights of 1791: "[T]he exercise of the

1303 LANCELLOTTO, op. cit. supra note 123 , at tit. 9 , § 1 .

1313 id. tit. 9, § 6.

132 ESMETN 471-84, 608-53, 815-32.

133 Rocr, op. cit. supra note 11, at 154-60.

134 The writers of the Enlightenment were welcomed in some parts of Paris society. Their tactics in reforming the thought of the 18th century Diderot descrihes in the metaphor of the "strange god": "The rule of Nature and of my Trimty, against which the gates of Hell shall not prevail, . . establishes itself very quietly. The strange god settles himself humbly on the altar beside the god of the country. Little by little le establishes himself more firmly. Then one fine morning he gives his neighbor a shove with his elbow and-crash $1-$ the idol lies upon the ground." Moore, Three TACTics: TaE Background IN MARX 95-96 (1964), quoting Diderot's Rameau's Nephew. On the influence of the Enlightenment, see ESMEIN, L'HISTOIRE DU DROIT FRANÇATS DE 1789 A 1814 at 3-5; Friedrich, The Ideological and Philosophical Background, in THe CODE NAPOLEON 1 (Schwartz ed. 1956).

135 Friedrich, supra note 134, at 6; ESMEn, op. cit. supra note 134, at 329-30. Esmein cited Domat, Pothier and Bourjon as preeminent among jurists whose work directly influenced the codifiers. 
natural rights of each man has no limits other than those that ensure to other members of society enjoyment of those same rights. These limits can be determined only by statute."186 As Cambacères said to the Conseil d'Etat in presenting an early Code draft: "[I]t is indispensable to substitute for the old laws a code ... which is at once the principle of social welfare and the safeguard of public morality."187 These same statements make evident the natural law bias of the revolutionary leaders.

Of the three goals-unification, certainty, and harmony with the natural law-the revolution emphasized natural law. When Napoleon ascended to the Consulate, however, he sought principally unification and certainty. ${ }^{188}$ Either way, the treatment of compensatio was the same.

The 1796 pre-Napoleon draft of the Civil Code contains six sections on compensatio. One section sets forth its operation: cross-demands, even those arising from different transactions, are automatically extinguished. ${ }^{189}$ Another section limits its application to liquid, presently due debts. ${ }^{140}$ A third provides that the consequences of automatic extinction include cessation of the running of interest. ${ }^{141}$ Other sections exclude "spendthrift legacies," interests of the state, and obligations to return a specific chattel from the operation of compensatio. ${ }^{142}$

The principles of "right reason" sought to be embodied in these sections happened also to be a synthesis of the French law of compensatio that developed during the 18th century. For the jurist of the Age of Reason, therefore, compensatio was respected for its venerable origins, and doubly to be praised for fitting into the natural order of things. ${ }^{148}$ Rationalists could accept the notion of automatic extinction of reciprocal obligations with the same ease that attended the reification of other political, ethical, and legal abstractions. This philosophical predisposition was supported by legal history and custom: Domat and Bourjon, in summarizing, respectively, the written and customary law, agreed on the

186 Quoted in Tunc, The Grand Outlines of the Code, in THE CoDE Naroleon 22 (Schwartz ed. 1956).

187 Projet du Code Civil (1796), Discours Preliminaire at 1 . This was the third draft of the Code, the first having been rejected as too cumbersome and ill-drafted, the second (a scant 297 articles) as too short. EsMEeT, op. cit. supra note 134, at 248-49.

188 Friedrich, supra note 134 , at 5-6.

139 Projet du Code Civil \& 802 (1796).

140 Id. $\S 803$.

$141 \mathrm{Id}$. 8805 .

142 Id. § 807 .

143 That compensatio was a principle of natural law, see, e.g., ZEILLER, DAS NATURLICEE Privat-Recht § 119 (1808): "All contracts have in common certain grounds of extinction regarding the rights and obligations founded thereon. Such are: .... compensatio as a shorthand payment, through liberating the creditor by the debtor from an obligation of the same type to be performed at that very time." See also 5 PUFENDORF, THE LAW OF NATURE AND Natrons ch. 11, §§ 5-6 (Kennett. transl. 4th ed. 1729). 
basic principles of compensatio. ${ }^{144}$ But the influence of Pothier far surpassed that of anyone else; he, too, urged a broadly-applicable law of automatic compensatio. ${ }^{145}$

Compensation, wrote Pothier, is a payment. In payment of an obligation, one cannot ask the creditor to accept a substance other than that due him. Thus, the two debts must be in the same coin: money for money, grain for grain, oil for oil. ${ }^{140}$ Further, the debts must be fully due, and liquidated; if one is indeterminate, compensation cannot take place. Pothier gives no reason wly this should be so, considering it suffcient to cite the Roman text. ${ }^{147}$ He also held that the debt must be due between the same persons, and in the same right. Tlus, a debt due from a liusband could not be compensated against a debt due the wife: a debt due $A$ as executor of $T$ could not be set off against a debt due from $A$ in his personal capacity. ${ }^{148}$ Pothier's notion of automatic compensation was derived from the words "ipso iure" in Justinian's Code, and by induction from the effects of compensatio which the Code and Digest set out: for example, suit upon the excess of the larger debt over the smaller, and cessation of the course of interest. ${ }^{149}$

Pothier's treatment formed, in the main, the basis of the Napoleonic Code's articles on compensatio. The Code followed Pothier rather than the 1796. Draft in allowing debts which were fungibles for fungibles, as well as money for money, to be compensated. ${ }^{\mathbf{1 5 0}}$ While the requirement of liquidity was retained, debts determined in amount by market prices publisled each day in the press were considered sufficiently determinate to be susceptible of compensation. ${ }^{151}$ In other details, the Code Napoleon iterated the rules stated by Pothier. ${ }^{\mathbf{1 5 2}}$

The requirement of liquidity provoked some discussion in the Conseil d'Etat, with one nember, Maleville, proposing that compensatio also be

144 Domat, op. cit. supra note 116, bk. 4, tit. 2; Bourjon, Le Dro1t CoMmun de aA France bk. 6, tit. 7, ch. 2 (3d ed. 1770).

145 Pothier §§ 623-40; see Friedrich, supra note 134, at 6. Pothier also gained great favor in England and America, a translation of his treatise on obligations being published in both countries. PIUCKNetT, A Concise Hustory of the CoMmon Law 265-66 (2d ed. 1936).

146 Pothier $\$ \$ 624,626$.

147 Id. $\$ 628$.

148 Id. $\S \S 630,632$.

149 Id. $\$ \S 635-36$.

150 Code Civil $\$ \S 1289-91$ (1804). The citations to the Napoleonic Code are taken from CoNfErence dU CODE CIVIL (1805), which contains the text of the sections, proposed amendments, and the discussion in the Conseil d'Etat. Pothier is discussed in text acconpanying note 145 supra, and in note 118 supra. The 1796 Draft is discussed in text accompanying notes 139-42 supra, and in note 137 supra.

151 Code Civil \$ 1291 (1804).

152 Code Civil $\$$ 1289-99 (1804). 
allowed when the amount of the debt was not certain, but capable of easily being made certain. ${ }^{153}$ This, said Maleville, was the Roman procedure. ${ }^{154}$ His colleagues, however, argued that compensation automatically and of right occurs only between liquidated sums. Maleville's point, argued Treilhard, is valid, but has nothing to do with this sort of situation. "When the action presents itself in the circumstances which M. Maleville has proposed, the judge, deferring to equity, will allow a delay for payment to take place, giving the debtor time to make his credit hquid and thereby accomplish compensation." 155 Another member said that interest did not cease to run upon the respective obligations until both were liquidated, demonstrating that there was no distinction between debts difficult and those easy to render certain in amount: neither were susceptible of automatic compensation. ${ }^{156}$ The requisite of liquidity was retained, the judge's discretion to do as Treilhard suggested being acknowledged but not codified. ${ }^{157}$ The policy of "avoiding the circuity of two payments"158 was limited by the policy of preventing defendants from prolonging the action with questionable claims propounded against debts clearly due. ${ }^{159}$

This treatment of compensatio spread to the countries which adopted the Code Napoleon. The Code, and Pothier, also exerted an indirect influence upon the law of cross-demands in England and America. The notion was pervasive that natural reason required that cross-demands be mutually extinguished.

\section{III}

\section{MANSFIELD AND STORY}

Both Mansfield and Story wrote of setoff; both were scholars and admirers of Roman and civil law. ${ }^{160}$ Each believed his conclusions to rest upon natural reason. Mansfield examined setoff in the statutes and precedents, summarized and coinmented, but innovated little. ${ }^{161}$ Story took Mansfield's comments, combined them with the French and Roman

1535 Conference du Code Civin 124-25 (1805).

$154 \mathrm{He}$ had support in Justinian. See CoDE 4.31 .14 , which can be read as allowing unliquidated claims which are not difficult of proof; the section may mean, however, that easily-proven liquidated claims are the only ones permitted.

1555 Conference du Code Crvil 125-26 (1805).

$156 I d$. at 126 . See text accompanying notes 6-9 supra.

1575 id. at 126.

158 The phrase occurs in Doxar, op. cit. supra note 116, at bk. 4, tit. 2, § 1, 『 2. 159 Code 4.31.14; 5 Conference du Code CivIr 125 (1805).

160 See PluckNeTr, op. cit. supra note 145, at 222-24; Leslie, Similarities in Lord Mansfield's and Joseph Story's View of Fundamental Law, 1 AM. J. Legar HIST. 278 (1957).

161 See his opinions in Howlet v. Strickland, 1 Cowp. 56, 98 Eng. Rep. 965 (K.B. 1774); Green v. Farmer, 4 Burr. 2214, 98 Eng. Rep. 154 (K.B. 1768); Baskerville v. Brown, 2 Burr. 1229, 97 Eng. Rep. 804 (K.B. 1761) ; Collins v. Collins, 2 Burr. 820, 97 Eng. Rep. 579 (K.B. 1759). 
law as he understood it, and regretted that compensatio had not been adopted by the common law. ${ }^{162}$ Story accepted at face value the French interpretation of the Roman texts: compensatio takes place automatically at the moment hquidated cross-demands coexist. In writing upon compensatio he therefore combines as no other influential legal scholar of the early nineteenth century exegesis of the civil law rules with advocacy of their adoption. By virtue of Story's advocacy and influence, one may infer that he influenced the progemitor of Section 440 of the Cahfornia Code of Civil Procedure.

\section{A. Early Common Law and Chancery Practice}

Mansfield wrote against a background of one hundred years of English cross-demand procedure. In the seventeenth century, commissioners in bankruptcy may have admitted setoffs between the bankrupt and a creditor to the extent of the smaller claim..$^{163}$ Chancery likewise allowed a setoff when the bankrupt or his representative sued a creditor. ${ }^{104}$ Mutual dealings between the bankrupt and another apparently led even the law side to declare the respective demands set off, so that the creditor was made to pay "that which appears due to the bankrupt at the foot of the account." 165

Setoff was recognized by statute in 1705 , but limited to the case of bankruptcy. ${ }^{186}$ Chancery, however, continued to allow setoff in other cases, where equity and justice demanded it. ${ }^{167}$ In 1729, Parliament. enacted a more general setoff statute, ${ }^{188}$ which was slightly expanded in 1735. ${ }^{169}$

Neither case law nor statute provided that setoff operate automatically to extinguish the respective claims. Setoff, or stoppage, as it was also termed, allowed the defendant to put in his claim as of the time of the suit; further, there was no penalty in saving the claim for a separate action. ${ }^{170}$ The English came closer, therefore, to reconventio, or mutual

1622 Story, CommentarIes on EQUity JURISPRUdENCE $\$ \$ 1433-49$ (2d ed. 1839) [heremafter cited as STORY]. There are many editions of Story; this one is chosen as baving been published in time for David Dudley Field to have read it.

163 Loyd, The Development of Set-Off, 64 U. PA. L. REv. 541, 547 (1916).

164 Id. at $547-49$.

165 Anonymous, 1 Mod. 215, 86 Eng. Rep. 837 (C.P. 1676).

1664 Anne, c. $17, \S 11$ (1705), amended by 5 Geo. 2, c. 30, $\$ 28$ (1732).

167 See Greene v. Darling, 10 Fed. Cas. 1144, 1147-48 (No. 5765) (C.C.D.R.I. 1828), tracing the practice in Chancery before and after the enactment of the statute of setoff.

1682 Geo. 2 , c. $22, \S 13$ (1729).

1698 Geo. 2 , c. $24, \S \S 4-5$ (1735).

170 Baskerville v. Brown, 2 Burr. 1229, 97 Eng. Rep. 804 (K.B. 1761). But in that case, Mansfield remarked that it was "litigious and vexatious" of Baskerville not to have set up his claim in Brown's action. Id. at 1231, 97 Eng. Rep. at 805. 
petitions, than to compensatio. Lord Chief Justice Gilbert, writing in 1758, attributed the cross-bill in Chancery to the civil law reconventio. ${ }^{171}$

Though automatic extinction of cross-demands did not take place as of right, Chancery had been quick to infer an agreement that it occur. As Jekyll, M.R., said in 1723:

It is true, stoppage is no payment at law, nor is it, of itself, payment in equity, but then a very slender agreement for discounting or allowing one debt out of the other, will make it a payment, because this prevents circuity of action and multiplicity of suits, which is not favored in law, much less in equity. ${ }^{172}$

Jekyll may, of course, have referred to the adjudicative act of setting off as "payment"; but his language in context seems rather to posit an implied agreement that reciprocal demands shall be set off automatically, only the balance being due at any given moment. But Jekyll spoke six years before the statute of setoff: when it was passed, the statute became the standard to which all questions of setoff were referred.

The eighteenth century rules articulated in response to the statute confined the right of setoff to hquidated, or easily ascertainable, demands. ${ }^{178}$ Setoff was a defense only; the defendant had to bring a separate suit to collect so much of his claim as exceeded that of the plaintiff. ${ }^{174}$ The setoff had to be due the defendant at the commencement of the action, ${ }^{175}$ and due him in the same capacity as that in which he was sued. ${ }^{176}$ This was the law that Mansfield confronted.

\section{B. Mansfield's Contribution}

In Green v. Farmer, ${ }^{17 \tau}$ plamtiff sued in trover for bolts of cloth left with the defendant to be dyed. The defendant sought to set off the cost of dyeing previous orders. In reaching his conclusion that setoff was not available, Mansfield said:

Natural equity says, that cross-demands should compensate each other,

171 Gitbert, The History and Practice of the High Court of Chancery 45-47 (1758).

172 Jeffs v. Wood, 2 P. Wms. 128, 129, 24 Eng. Rep. 668, 669 (Ch. 1723). Cf. Barbour, LAW OF SET-OFF 193 (1841). Mansfield held in Collins v. Collins, 2 Burr. 820, 825, 97 Eng. Rep. 579,582 (K.B. 1759), that by the statute of setoff, "stoppage . . . is become equivalent to actual payment: and a balance shall be struck, as in equity and justice it ought to be." He apparently means that setoff is as complete a defense as payment, so that the plaintiff may be nonsuited if the defendant shows an equal or greater demand owed himself from the plaintiff.

173 Howlet v. Strickland, 1 Cowp. 56, 98 Eng. Rep. 965 (K.B. 1774).

174 Baskerville v. Brown, 2 Burr. 1229, 1231, 97 Eng. Rep. 804, 805 (K.B. 1761).

176 Montagu, The Law of Set-off 20 (2d Am. ed. 1825).

178 Id. at $24-40$.

1774 Burr. 2214, 98 Eng. Rep. 154 (K.B. 1768). 
by deducting the less sum from the greater; and that the difference is the only sum which can be justly due.

But positive law, for the sake of the forms of proceeding and convenience of trial, has said that each must sue and recover separately..$^{178}$

To one learned in the civil law, "compensate" clearly meant the automatic extinction of cross-demands. Did Mansfield mean to affirm and adopt this principle? Or did he wish only to advert to the common law rule by way of contrast with a less strict mode of proceeding, and in doing so to use a word which had no technical significance in the common law courts?

The latter seems improbable. Mansfield's colleagues were likely to have at least a nodding acquaintance with Roman and French law; or Scots law, which was based on the Roman. Further, Mansfield himself was a student of Roman law in two important ways. First, he had a respect for the Roman legal tradition based upon an understanding and study of it. Second, he came to the bar as a Scots lawyer. Scotland, with a system of jurisprudence independent of England to this day, is a civil law jurisdiction. Compensatio, translated compensation, was known and used in Scots law. ${ }^{179}$ Under that law, however, compensation did not operate as a payment, to stop the running of the statute of limitations, though it niay have operated automatically to stop the running of interest. ${ }^{180}$

Mansfield was schooled in this law, as well as the classical Roman law. It is a permissible surmise that he meant to state the consonance of the Roman rule with the principles of natural justice. Story interpreted Mansfield as intending to state the cross-demand procedure in Chancery: where there were cross-demands involving a natural equity, the Chancellor would declare them extinguished to the extent of the lesser debt. ${ }^{181}$ This

178 Id. at 2220, 98 Eng. Rep. at 157.

179 See 2 BeIl, Comorentapies on the Law of Scotrand *126-*40; StaIr, The Inst1TUTTONS OF THE LAw OF ScOTLAND bk. 1, tit. 18, \& 6 (2d ed. 1693). Lord Stair states that compensatio takes place ipso iure to stop the running of interest, but that it must be invoked by either party or by a third person. When invoked, it operates retrospectively to the time when the deinands first coexisted. Id. at 153-54. See Queen v. Bishop of Aberdeen (1543), set forth in Barfour, Practicks 349 (1754), the 1962 Stair Society facsimile edition of which was consulted. That case denied the Bishop compensatio, perhaps because he attempted to assert his cross-demand against the sovereign. Scotland clearly had compensatio after 1592, when the Scottish Parlianient passed a statute providing for it. 3 Tre Acrs of tHe ParitaMIENTS OF SCOTLAND 573 (Thomson ed. 1814): "THAT compensatioun de liquido ad liquidum be admittit in all Jugementis. Oure Souerane Lord and estatis of parliament statutis and Ordanis that ony debt de liquido ad liquidum instantlie verifiet be wreit or aith of the partie befoir the geving of decreit, be admittit be all the Jugis within this realn be way of exceptioun. Bot not eftir the geving thairof, In the suspension or in reduction of pe same decreit." (The cited collection was compiled at the direction of the British Crown.)

180 BEIL, op. cit. supra note 179, at *130; STAIR, op. cit. supra note 179, bk. 1, tit. 18, $\S 6$, at $153-54$.

181 StoRy §§ 1432, 1435; Greene v. Darling, 10 Fed. Cas. 1144, 1147 (No. 5765) (C.C.D.R.I. 1828) (Story, J., on circuit). 
view, and Story's favorable comment upon compensatio in Rome and France, deserve closer attention.

\section{Joseph Story}

In an 1828 federal case, Greene v. Darling, ${ }^{182}$ Justice Story, on circuit, considered setoff im detail. Reviewing the cases in England and America, he set forth two propositions. First, absent a statute of setoff, and absent reasons of equity, the bare existence of mutual unconnected debts between plaimtiff and defendant would not move the Chancellor to decree a setoff. Second, no right of setoff would travel with a note; thus, a subsequent holder was not in danger of having his action on the note defeated by the obligor's claim against the original payee.

The first proposition was based on the absence of any evidence of "mutual credit" to justify equity intervening. In his Commentaries on Equity Jurisprudence, Story defined mutual credit as

a knowledge on both sides of an existing debt due to one party, and a credit by the other party, founded on, and trusting to such debt, as a means of discharging it. Thus, for example, if $\mathrm{A}$. should be indebted to $B$. in the sum of $£ 2,000$ on his own bond, the bonds being payable at different times, the nature of the transaction would lead to the presumption, that there was a mutual credit between the parties, as to the $£ 2,000$, as an ultimate set-off, pro tanto, from the debt of $\notin 10,000.183$

Were the bonds payable at the same time, it would be practically certain that a compensation was intended. Unless the plaintiff could give a compelling reason not to, equity would enforce a setoff. ${ }^{184}$

Story discussed his second proposition in these terms:

Where a chose in action is assigned, ... the assignee takes it subject to all the equities existing between the original parties, as to that very chose in action, so assigned. But that is very different from admitting, that he takes subject to all equities subsisting between the parties as to other debts or transactions. . . An assignment of a chose in action. conveys merely the rights, which the assignor then possesses to that thing. But such an assignment does not necessarily draw after it all other equities of an independent nature. Then, again, what is the right of setoff? By our law it is not a compensation, balancing debts pro tanto .... ${ }^{185}$

Justice Story's exposition in Greene v. Darling was an account of the case law of setoff in 1828; Story regarded it as sufficiently accurate to cite his opinion extensively in his Commentaries on Equity Jurispru-

182 Supra note 181.

183 STORY § 1435, at 659-60.

184 Id. § 1435, at 660 .

18510 Fed. Cas. at 1149. 
dence. ${ }^{188}$ Story did more than state rules of law in the Commentaries, however; he discussed compensatio at Roman and French law, citing Justinian, Domat, and Pothier. ${ }^{187}$ Changing his style from expositor of the law as it was, to advocate of rules of law that ought to be, Story concluded it "a matter of regret" that the principles of Roman compensatio
have not been transferred to their full extent into our system of Equity jurisprudence. Why, indeed, in all cases of mutual debts, independently of any notion of mutual credit, Courts of Equity should not have at once supported and enforced the doctrine of the universal right of set- off, as a matter of conscience and natural equity, it is not easy to say. Having affirmed the natural equity, it seems difficult to account for the ground, upon which they have refused the proper relief founded upon it. ... The doctrine of compensation has, indeed, been felicitously said to be among those things, quae jure aperto nituntur [which to be appreciated need but to be seen]. ${ }^{188}$

Story recognized and accepted the French view that compensatio takes place automatically; the paragraph quoted seems to advocate that all mutual debts which the civil law would compensate should be, at common law, extingnished to the amount they are equal and from the time they coexist. But the quoted paragraph is ambiguous: it first speaks of adopting the "principles" of compensatio, next of the "doctrine" of compensatio, and finally of adopting "it" as all the Roman law countries have done. ${ }^{189}$ Perhaps Story meant only to say that judicial offset should be allowed in all cases where the civil law allows compensatio. Whatever the intended thrust of his elliptical advocacy, Story evidently affirmed the reason and justice of the civil law rule as constructed by Pothier from fragnients of Justinian.

Story's reputation, the fame of Greene v. Darling, the pervasive influence of his Commentaries, the language of his advocacy: these allow an inference that Field drew the principle of what is now California Code of Civil Procedure section 440 largely from Story, supplemented by Field's own acquaintance with the civil law. This contention deserves closer examination.

\section{IV}

THE LEGISLATIVE HISTORY OF SECTION 440

\section{A. New York}

David Dudley Field began to write and agitate about reform of civil procedure in $1839 ;^{190}$ he influenced passage of a New York constitutional

186 STORY \$ 1436 n.1.

187 Id. $\$ \S 1438-44$.

188 Id. $\S 1444$.

189 Ibid.

190 H. M. Field, The LfFe of David Dudeey Field 46 (1898). 
amendment of 1846 providing for reform, ${ }^{191}$ and took his place as one of three Commissioners on Practice and Pleading. ${ }^{192}$ The first installment of the Code of Civil Procedure was reported in February 1848 and passed in April. ${ }^{193}$ It abolished the forms of action and sought to simplify pleading; the distinction between law and equity was, in part, maintained. As the 1848 Code did not provide for cross-demands, and as it left the former law standing where its provisions did not run, the New York law of setoff remained as it had been before: roughly like the English. ${ }^{194}$

In 1850, the Commissioners reported a complete Code, annotated and discussed. ${ }^{195}$ By that time, the opposition to codification had grown among judges and legislators; the 1850 Proposed Code was never adopted in its entirety. ${ }^{180}$ Instead, the 1848 Code was amended in $1851^{197}$ and 1852. ${ }^{198}$ The 1852 amendments incorporated, with minor changes, the 1850 Proposed Code section defining a counterclaim. ${ }^{199}$ The Proposed Code allowed a counterclaim where the defendant's demand arose from the contract or transaction sued upon, or was "connected with the subject of the action"; also, when the plaintiff's demand arose "on obligation," the defendant could plead "any other cause of action arising also on obligation, and existing at the commencement of the action."200

The New York legislafure, however, rejected section 648 of the 1850 Proposed Code:

When cross-demands have existed between persons, under such cir-

181 Id. at 46-47; Reppy, The Field Codification Concept, in Davm Dodrey Fiewd CenTENARY Essays 31-32 (Reppy ed. 1949).

192 FIELD, op. cit. supre note 190, at 49. The original commission included Nicholas Hill, David Graham, and Arphaxad Loomis, Ficld being rejected as too radical. Hill soon resigned and the legislature appointed Ficld in his stead.

193 FIErd, op. cit. supra note 190, at 49; Reppy, supra note 191, at 33-34; N.Y. Laws ch. 379 (1848).

184 Reppy, supra note 191 , at 34 ; N.Y. Laws ch. 379 , $\$ 388-90$ (1848). The New York setoff statute was originally borrowed from that of Pennsylvania in 1714, Loyd, supra note 163, at 558-59; 1 ColONIAL LAwS OF NEw YORK 827 (1894). The act was similar to the English statute. New York expanded its setoff provisions in 1813, but again constricted them in 1830. N.Y. Laws ch. 56 (1813); BARBOUR, LAW OF SET-OFF 25 (1841). See Reab v. McAlister, 8 Wend. 109 (N.Y. Ct. Corr. Err. 1831), construing the 1813 and 1830 statutes together and conlmenting upon their differences. But see Duncan v. Lyon, 3 Johns Ch. 271 (N.Y. Ch. 1818), in which Chancellor Kent discusses the civil law and statutory setoff.

185 Their Final Report was dated Dec. 31, 1849, but was printed with the Proposed Code in 1850. See Hepburn, The HistoricaI Developarent of Code Pleadrag § 141 (1897) [hereinafter cited as HEPBURN].

196 See, e.g., the acerb comments upon the Code in Roscoe v. Maison, 7 How. Pr. 121,

123 (N.Y. Sup. Ct. 1852); HEPBURN § 141.

197 N.Y. Laws chs. 2, 479 (1851).

198 N.Y. Laws ch. 392 (1852).

199 N.Y. Laws ch. 392 , § 150 (1852).

200 Comanassioners on Practice and Pleading, Proposed Code of Civil Procedure, Reported Decearber 31, $1849 \& 646$ (1850) [hereinafter cited as 1850 Proposed Code]. 
cumstances, that if one had brought an action against the other, a counterclaim could have been set up, neither can be deprived of the benefit thereof, by the assignment or death of the other, but the two demands shall be deemed compensated, so far as they equal each other.

Where did Field draw this language and what did he mean by it? To neither question is there a sure answer. A persuasive argument can be made that David Field drew the inspiration for 1850 Proposed Code section 648 from the Commentaries on Equity Jurisprudence. There are, however, other contemporary statements couched in the language of the civil law; they, too, deserve examination. Mansfield's dictum, that natural equity says cross-demands should be compensated, ${ }^{201}$ was, of course, a famous utterance. It occurred, for example, on the first page of the first English treatise on setoff, published in London late in the eighteenth century. This work, by Montagu, was also widely used in America. ${ }^{202}$

Montagu was displaced in America by Barbour's work on setoff, ${ }^{203}$ which, designed for the American practitioner, particularly detailed the New York law. Barbour did not acknowledge his evident debt to Mansfield, but he said "it is a principle of natural reason and justice that a claim due from the plaintiff in an action, to the defendant, should compensate the demand sued for, as far as it will go, and that the balance only should be recovered." 204

And in Reab v. McAlister, ${ }^{205}$ an 1831 New York case, these words appear:

There is a natural equity, especially as to claims arising out of the same transaction, that one claim should compensate the other, and that the balance only should be recovered. This natural equity was by the civil law extended even to unconnected claims which were liquidated or were capable of hquidation by mere computation. But the common law of England required ... separate actions. . . . ${ }^{206}$

But common law reports and treatises were not all that Field had to draw upon.

Pothier's work on obligations was familiar, principally in a two-volume edition by Evans. ${ }^{207}$ Evans' first volume was a barely-adequate translation of Pothier. The second volume contained annotations of the first, with comparison of civil and common law rules. Evans' note "Of Com-

201 Green v. Farmer, 4 Burr. 2214, 2220, 98 Eng. Rep. 154, 157 (K.B. 1768).

202 Montage, The LAw of SET-OFF 1 (2d Am. ed. 1825). The book was originally published in 1801.

203 BARBOUR, LAW OF SET-OFF (1841); see Barbour's just evaluation of Montagu in his Preface at $v$.

204 Id. at 22-23.

2058 Wend. 109 (N.Y. Ct. Corr. Err. 1831).

200 Id. at 115.

207 Pothier, Law of Obligations (Evans transl. 3d Am. ed. 1853). 
pensation, or setoff" begins: "It is evidently a principle of natural reason and justice, that when two parties are mutually indebted, the balance only shall be paid; and that one of the parties shall not be compellable to pay the debt which he has incurred, and be left to sue for that to which he is entitled."2208

Add to this David Field's evident familiarity with the civil law; ${ }^{209}$ for example, his proposed counterclaim section adopts the civil law term "obligation" instead of "contract." Division III of the Field Civil Code, in arrangement and content, owes an evident debt to the Code Napoleon. ${ }^{210}$

Why, of all the available influences, single out Story? The answer lies in his treatment of assigned cross-demands, with which 1850 Proposed Code Section 648 principally deals. For of all the common law writers, Story alone considers the two matters side by side; he alone commends the civil law rule of compensation not only as a principle of natural justice but as a workable rule of practice. ${ }^{211}$

To accept this view, or to reject it, is not to end the inquiry; the language of section 648 is ambiguous. What did Field mean to enact? Does the statute mean only that assignment of a note carries with it the counterclaims subsisting against the assignor and in favor of the obligor of the note, which claims may be set off by a judge at the time of suit? This reading would give effect to section 648 's command that "when cross demands" which could be counterclaims "have existed between persons . . . neither shall be deprived of the benefit thereof by the assignment... of the other" by allowing these demands to be "deemed compensated"-that is, set off-when the assignee sued the obligor. "Compensate," by this view, does not import civil law principles but is a generic term denoting judicial offset. This reading would overrule Greene v. Darling $^{212}$ and allow setoff against assignees even when the defendantobligor could not show some equitable reason justifying it; the same treatinent would be given claims of one sued by an executor on obligations arising in the decedent's lifetime.

A second possible reading would be that two demands which coexist and satisfy the counterclaim requirement shall automatically extinguish each other "so far as they are equal." Thus, when an assignee or executor

2082 id. at 96.

200 See Parma, History of the Adoption of the Codes of California, 22 L. LIB. J. 8, 19 (1929); FIEID, op. cit. supra note 190, at 44; David Field contrasted and discussed several European Codes in a letter to inembers of the California Bar in 1870. Cosmassion FOR THE Reviston and Reform of the Laws, Law Reforar Correspondence Between the Revision Comantssion aNd Davm DUdeEY FIELd 11-13 (1871).

210 Parma, supra note 209, at 19.

211 See text accompanying notes $182-88$ supra.

21210 Fed. Cas. 1144 (No. 5765) (C.C.D.R.I. 1828). See text accompanying notes 18286 supra. 
sues, the judge must recognize this legal payment by adjudicating, or "deeming," the demands to have been "compensated." By this view, the words "neither can be deprived of the benefit thereof, by the assignment or death of the other," illustrate, but do not limit, the operation of the section. For, if the word "compensate" means automatic extinction, the original parties to a note or obligation can plead this "legal payment" as well between themselves as against an assignee or executor. Field, read this way, adopts Story's suggestion in Greene v. Darling that compensatio is one way to solve the problem of setoff against assigned claims. ${ }^{213}$

Which of the two, if either, expresses Field's intent is impossible to say. Field did choose the word "compensate." To a French jurist, the word means but one thing: automatic extinction of cross-demands. Field cannot have escaped knowing that; the setting of the word among provisions dealing with cross-demands may demonstrate an intention to use it in its technical sense. But again, "compensation" miglit easily be a generic term for cancelling cross-demands. Evans, like so many who translate "compensatio," rendered it "setoff"; the words may have been, in some minds, interchangeable. Field may have meant to adopt "compensate," a word without technical meaning in the conmon law, solely to express his new thoughts about cross-demands; the term "counterclaim" was, after all, Field's innovation. ${ }^{214}$ And Story was unclear im his advocacy of civil law compensation; ${ }^{215}$ did he mean only that his holding in Greene $v$. Darling should be overruled, or that the civil law rule should be adopted without limit?

Field's annotations to the 1850 Proposed Code illuminate this question only partially. Field notes, in discussing his section on counterclaim, that setoff is quite limited in its operation, and recoupment is a fairly recent court-made cross-demand, ${ }^{216}$ confined to claims arising from the transaction sued upon. He proposes "to open the door still wider" with the counterclaim section, "and to admit many cross-demands, now excluded. Further experience may show, that the door should be opened wider still."217 Field seems to be referring, in his "door-opening" metaphor, to an increase in the number of demands which may be set off, not to a change

213 Id. at $1148-49$.

214 John Norton Pomeroy, in a series of articles written after California's codification, excoriated Ficld's semantic inventiveness, which he found indulged throughout the Field Codes. Pomeroy, The True Method of Interpreting the Civil Code, 3 West Const Reporter 585, 657, 717, 4 West CoAst Reporter 1, 49, 109, 145 (1884). Pomeroy's initial excoriation of the codifier's "constant, but wholly unnecessary practice of abandoning well known legal ternis and phrases" appears at 3 WEST COAST REPORTER 586.

215 STORY \& 1144.

216 See note 9 supra.

2171850 Proposed CODE \& 646, Commissioners' Note. 
in the manner in which they may be set off. His language does not bespeak a radical change in cross-demand procedure but a short step toward reform.

A final matter: Civil law compensatio was available only for liquidated demands; Field's counterclaim provided for unliquidated cross-demands. Section 648 adopted the counterclaim as the measure of when compensation is allowed. To suppose that Field intended to enact automatic compensation is to suppose that he meant not only to import the civil law rule, but to go far beyond it. This is improbable. It is reasonable to suppose that Field would have announced sucl a startling innovation with some explanation of his intention, especially in view of the section's limping prose. But section 648 was given not a syllable of annotation.

Whatever David Field's intent, and whatever his imspiration, the elliptical language of 1850 Proposed Code Section 648 was not adopted in New York. Legislative approbation was first given it in California. Twenty-three years after its 1851 adoption, section 440 took on its present form, and came to require unmistakably automatic extinction of crossdemands. The men who amended section 440 could scarcely have escaped knowing the impact of their language upon the scope of the section's operation.

\section{B. California}

As the Final Report of the New York Commissioners on Practice and Pleadings and the 1850 Proposed Code neared completion, in December 1849, Stephen Field came to California. ${ }^{218} \mathrm{He}$ was elected to the Assembly in 1850 and began his service at Sacramento in January $1851 .^{219}$ By Stephen Field's own account: "I took up the Code of Civil Procedure, as reported by the Commissioners in New York, remodelled it so as to adapt it to the different conditions of things and the different organization of the courts in California, and secured its passage. ${ }^{1220}$ Of all Field's statements about his legislative prowess-and he claims credit for nuch of the legislation enacted during his two-year term ${ }^{221}$ - he may with most justice be lronored for introducing the 1850 Proposed Code into California.

The California Civil Practice Act of $1850,{ }^{222}$ borrowed from the New York Act of $1848,{ }^{223}$ had abolished in some measure the distinction be-

218 S. FIeId, Eariy Days IN CaLIFornia 9-11 (1880); Pomeroy, Introductory Sketch, in Some Account of THE WORK OF STEPHEN J. FIEID 11 (1881); this sketch was amended and, as amended, approved by Field himself. See Letter from Stephen J. Field to John $N$. Pomeroy, June 21, 1881, in the Rare Books Department of the Main Library, University of California, Berkeley.

218 S. FIEID, op. cit. supra note 218 , at $24,56-65,221-23$.

220 Id. at 76.

221 Id. at 73-81, 85-89.

222 Cal. Stats. ch. 142 (1850).

223 Contrary to oft-expressed supposition, see, e.g., Hazard \& Loutseix, Cases on Plead- 
tween law and equity. The Civil Practice Act of 1851 enacted David Field's Proposed Code of 1850. In California's 1851 Act, section 48 repeated almost without change section 648 of the 1850 Proposed Code. With that enactment, California became the first state to enact David Field's system of pleading in the form in which he finally expounded it. ${ }^{24}$ There were, however, no reported cases construing Civil Practice Act section 48 when the California Code Commissioners drafted and annotated the 1872 California Code of Civil Procedure. The Code Commissioners, in adopting Civil Practice Act section 48 as Code of Civil Procedure section 440, noted:

Although a party may set up an equitable defense to an action at law, his remedy is not confined to that proceeding. He may let the judgment go against him at law, and file his bill in equity for relief.205

This language inplies that section 440 has to do with equitable setoff in an action at law; hence, the section would merely overrule Greene v. Darling. ${ }^{226}$ That, in the Commissioners' view, the equitable cross-demand can be saved for another action indicates that it has not been automatically extinguished by the plaintiff's demand.

The Commissioners changed the text of Civil Practice Act section 48 in drafting section 440 of the Code of Civil Procedure, adding a new sentence at the end:

But a claim existing in favor of the maker of a negotiable instrument and against a holder after maturity, intermediate between the payee and the last holder, is not a cross-demand. ${ }^{227}$

$\bar{T}$ his addition was evidently intended to protect the negotiability of commercial paper. ${ }^{228}$

But neither the Code of Civil Procedure nor section 440 were in final

ING AND Procedure 37 (1962), Stephen Field did not introduce the Field Code into California. He only brouglit the latest edition. Elisha 0 . Crosby, chairman of the Judiciary Committec of the state senate, drafted California's 1850 Civil Practice Act, using the New York Act of 1848 as a guide. Parma, supra note 209, at 12; HISTORY OF THE BENCH AND BAR OF CaLTFORNIA 48-49 (Sliuck ed. 1901). Crosby was also famous as the author, or co-author, of the report urging the legislature to adopt the common law rather than the civil law. $I d$. at $48-53$; 1 Cal. 588 (1850).

224 By virtue of other states following eitler the California Civil Practice Act of 1851, or the 1850 Proposed Code, the Field section on compensation of cross-demands was introduced into the law of other jurisdictions. HePbURN \$\$ 88-122; Clark, Code Pleading $\$ 106$, at 680 n.172 (2d ed. 1947); Kan. Gen. Stats. § 60-715 (1949); Neb. Rev. Stats. § 25-818 (1943); Orla. Stats. § 12-278; Mont. Stats. § 93-3409 (1964); OHIo Rzv. Code § 2309.19 (1953).

225 Cal. Code Civ. Proc. $\$ 440$ (1872), Commissioners' Note. See Lorraine v. Long, 6 Cal. 453 (1856).

22610 Fed. Cas. 1144 (No. 5765) (C.C.D.R.I. 1828).

227 Cal. Code Civ. Proc. $\$ 440$ (1872).

228 It echoes a similar exception for negotiable paper in CAL. Code Civ. Proc. $\$ 368$, relating to assignment of choses in action. 
form. Eleven days after the enactment of the Code, a "revision commission" was authorized by the legislature. ${ }^{229}$ To this commission, Governor Booth appointed Stephen J. Field, then a Justice of the United States Supreme Court, Jackson Temple, a former Justice of the California Supreme Court, and John Dwinelle, a leading member of the San Francisco bar. ${ }^{230}$ Working with the Code Commissioners, who were continued in office, ${ }^{231}$ this Commission to Examine the Codes functioned from June to October 1873. ${ }^{232}$ The Commission souglit to focus California legal thinking upon improving the Codes, soliciting suggestions from leading citizens; $;^{238}$ it prepared five draft acts of amendments, whicl it published with annotations in October 1873.234 The draft acts were the basis for extensive amendments to the Codes at the next session of the legislature. ${ }^{235}$

One of the amendments wrought Code of Civil Procedure section 440 into its present form:

220 Parma, supra note 209 , at 18.

230 Jackson Temple had been a justice of the California Supreme Court from 1870 to 1872; after his term expired, he went into practice with Governor Henry Haight, who left the governorship at the same time Temple left the court. HISTORY OF THE BENCH AND BAR OF CAIIFORNIA 660-61 (Shuck ed. 1901). Dwinelle, whose biography is sketched in id. at 46566, was apparently nominated to the Commission to Examine the Codes as a second choice. A letter from Henry Haight to Jackson Temple dated June 1873 (in the Bancroft Library, University of California, Berkeley) says that "Gov. Booth has selected you with Judge Field and Sawyer to prepare amendments to the Code." Sawyer could be either E.O. Sawyer, listed on the letterhead as Haight's law partner, or Lorenzo Sawyer, one of the group of lawyers who corresponded with David Field about the 1872 codification. See note 209 supra.

231 Commisston to Examtine tae Codes, Report of Oct. 11, 1873, at 4; Van Alstyne, The California Civil Code, in West's Ans. CAL. Crv. Code 17 (1954).

232 The Commission, in its report of Oct. 11, 1873, at p.4, reports that it organized itself on June 21, 1873. Its draft acts to amend the codes, primted in a volume entitled Report of Messrs. Fiedd, Tearple, and Dwtelele as Examtners of the Codes, SubarrTted Oct. 13, 1873, all bear the date Oct. 13, 1873. See Kleps, The Revision and Codification of California Law 1849-1953, 42 CAIIF. L. Rev. 766, 777-78 (1954).

$233 \mathrm{~A}$ copy of the form letter soliciting suggestions is pasted in a scrapbook in the Bancroft Library, University of Califormia, Berkeley: DwINeIre, Some of My OwN Sins 152 (no date). The scrapbook covers the period 1859-73. That the Commission took oral testimony is attested by its willingness to do so expressed in the letter, by its own report, and by a letter from Charles R. Story to Stephen J. Field, July 6, 1887, in Rare Books Department, Main Library, University of California, Berkeley, recalling the writer's testimony before Justice Field. A number of the written suggestions were acknowledged, and even quoted, in the annotations to the draft acts to amend the codes, contained in REPORT or MessRs Fieid, Texmple, and Dwineile as Examctners of the Codes, Submitied Oct. 13, 1873.

234 See notes 230-33 supra. These draft acts are, to the author's knowledge, collected nowlere other than in the Report. The Report, in turn, apparently survives only in the San Francisco Law Library, City Hall, San Francisco. Given the acknowledged usefulness of the 1872 Code Commissioner's Notes, see, e.g., People v. Vogel, 46 Cal. 2d 798, 299 P.2d 850 (1956) (Commissioners' annotation to Cal. Pen. Code $\S 20$ the basis of authoritative construction), it is surprising that the exposition of the 1874 anendments in the Report las not beretofore been unearthed and used.

235 The Amendments are collected in a volume separate from the other statutes, entitled Antendments to the Codes, 1873-74. 
When cross-demands have existed between persons under such circumstances that, if one had brought an action against the other, a counterclaim could have been set up, the two demands shall be deemed compensated, so far as they equal each other, and neither can be deprived of the benefit thereof by the assignment or death of the other. ${ }^{23 b}$

This change in wording was not annotated by the Commission as were most of the proposed amendments; hence there is no sure clue to its source. But it was introduced into the Assembly in 1874, was passed, and was signed into law in March $1874 .{ }^{237}$

The new wording of section 440 practically forecloses a reading which restricts its operation to cases of death and assignment: ${ }^{238}$ deeming demands "compensated" becomes the significant language, and the words about death and assignment are relegated to a position where they may be only illustrative. Granted, the new section talks of deeming demands compensated, and not of their automatic extinction. One could argue that the change in word order is intended to signify no change in meaning, but merely to correct the doubtful syntax of its predecessor section.

Two salient facts must be pointed out, however. First, John Dwinelle, one of the Commissioners, was a man of great learning in history and the law. ${ }^{239}$ That le knew of the civil law rule on compensatio may be assumed. Dwinelle had in 1850 led a group of San Francisco lawyers in urging the state legislature to adopt, "in its substantial elenients, the system of the Civil Law." ${ }^{240}$ Second, in November 1873 the supreme court gave its first interpretation of section 440 as it stood in Civil Practice Act section 48 and in the 1872 Code. While this case, Hart v. Cooper, ${ }^{241}$ was decided after the Commission to Examine the Codes finished its work, it illustrates a reading of section 440 which prevailed among judges at the time the Commissioners worked.

Hart sued on a note of Cooper's of which he was the assignee. Cooper had made the note originally to Mead. Cooper pleaded that before notice of the assignment, Mead had beconie indebted to him in the amount of 235 dollars, and he counterclaimed for that amount. At trial, Hart slowed that Cooper owed Mead 200 dollars, incurred at about the same time as the 235 dollars owed Cooper. The supreme court might have adopted the

236 CaL. Amendments to the Codes ch. $383, \S 53$ (1874). The bill to amend was A.B. 102 at the twentieth session of the legislature.

237 ASSEMabLy JouRnat, 20th Sess. 1089 (1874).

238 Compare text accompanying notes 212-13 supra.

239 This is indicated in the material collected in DwniburE, op. cit. supra note 233. See also History OF THE BENCH AND BAR OF CALIFORNIA 456-66 (Shuck ed. 1901).

240 Senate Journax, 1st Sess. 126 (1850); the letter was in support of a similar proposal to the legislature by Governor Burnett. See Parma, supra note 209, at 10-11.

24147 Cal. 77 (1873). 
trial court's finding ${ }^{242}$ that the demands between Mead and Cooper were mutual credits; on that basis, the court could find an implied agreement that, at any given moment, only the balance of the account would be an outstanding claim. Story could liave been cited for that application of the law to the facts found in the lower court. ${ }^{243}$ But the court rested on section 440, paraplirasing its words: "The two demands [between Cooper and Mead] were cross-demands, and must be deemed compensated so far as they equalled each other."244

The Commissioners to Examine the Codes may well have liad a similar view of section 440 , which they sought to render in language more apt. But there is no demonstrable connection between the case and their deliberations, save one of time and point of view. This "point of view" found expression in the California cases.

\section{$\mathrm{V}$}

THE CALIFORNIA CASES

Between 1873 and 1946, section 440 was subjected to various constructions in a series of cases principally notable for not citing one another; the "law" about section 440 was a series of rulings inexplicable as reasoned efforts to develop a consistent policy toward a potent defendant's weapon. In 1946, however, the supreme court decided the first of what have become three leading cases construing the section. This 1946 case, Jones v. Mortimer, ${ }^{245}$ and two which followed it, ${ }^{246}$ provide a framework within which to view the prior and subsequent case law of section 440 .

\section{A. Jones v. Mortimer and its Progeny}

The plaintiff in Jones was both shareholder and creditor of an insolvent savings and loan association. As holder of four shares he was in 1939 assessed four hundred dollars to pay the association's debts. In 1940 , he obtained a judgment for $\$ 1536$ for services rendered the association in its solvent days. The defendant Building and Loan Commissioner, successor-in-interest to the association, did not press the four hundred dollar claim in the plaintiff's action, but four years later successfully moved to block execution on the plaintiff's judgment. The plaintiff argued that the statute of limitation barred the Commissioner's claim. The court rejected this argument in an extensive analysis of section 440 .

242 Transcript on Appeal, pp. 12-14, Hart v. Cooper, 47 Cal. 77 (1873); neither briefs, nor trial transcript, cite $\S 440$. It was either first mentioned on argument or applied by the court of its own accord.

243 STORY \& 1435.

24447 Cal. 77, 79 (1873).

24528 Cal. 2d 627, 170 P.2d 893 (1946).

240 Sunrise Produce Co, v. Malovich, 101 Cal. App. 2d 520, 225 P.2d 973 (1950);

Hauger v. Gates, 42 Cal. 2d 752, 269 P.2d 609 (1954). 
The cross demands here, in the language of section 440, "have existed between persons"-plaintiff and defendant. They existed between them at least at the time the assessment became due and the plaintiff's action on his claim was pending. They have existed under circumstances where if either brought an action thereon the other could have set up a counterclaim. . . . The next step is that the demands are compensated. That can mean nothing more or less than that each of the claimants is paid to the extent that their claims are equal. To the extent that they are paid, how can the statute of limitations run on either of them? There is no outstanding claim on which the statute may run. ${ }^{247}$

Taken at face value the court's language comes down squarely for automatic extinction of all cross-demands which satisfy the counterclaim requirement. ${ }^{248}$ Given the breadth of California's counterclaim, this covers a wide ground. ${ }^{249}$ Further, the court's language treats this process of cancellation as occurring independently of the will of either party, with no requisite of notice. Certainly that was the case in Jones $v$. Mortimer. The automatic compensation having taken place, it was sufficient to point to it years later; the court's only caveat was that defenses to the respective demands must be heard. ${ }^{250}$ Consider as well the court's attitude that the "fact" of automatic compensation relieved the Commissioner of the duties customarily visited upon a defendant in framing lis pleadings. Accept that section 440 accomphislied "payment" of the respective claims to the extent they were equal; payment, traditionally an affirmative defense, is

$24728 \mathrm{Cal} .2 \mathrm{~d} 627,632,170 \mathrm{P} .2 \mathrm{~d}$ 893, 897 (1946) (alternative holding) (emphasis in original). The court distinguished Lyon v. Petty, 65 Cal. 324, 4 Pac. 103 (1884), which had beld that claims barred by the statute of limitation could not be asserted under $\$ 440$. The court in Lyon rested its holding upon a provision of $\S 438$ of the Code of Civil Procedure as it then stood, requiring that a counterclaim coexist with the plaintiff's claim at the commencement of the action. That is, the statute of limitation could not have run when the plaintiff filed his action. Moore v. Gould, 151 Cal. 723, 91 Pac. 616 (1907) cast doubt on the holding in Lyon, and the legislature in 1927 did away with the requirement that a counterclaim exist at the commencement of the action. Cal. Stats. ch. 813 (1927).

248 The language in Jones about the statute of limitation and $\S 440$ is an alternative holding. The court noted that the statute of limitation is tolled on a counterclaim when the plaintiff files his action. Since the statute had not run on the Commissioner's claim when Jones filed suit, and since Jones's execution proceeding could he considered "a continuation of the plaintiff's action," the Commissioner's counterclaim might be sustained on that ground as well. 28 Cal. 2d 627, 633-34, 170 P.2d 893, 897 (1946). Regarding an execution proceeding as a continuation of the original action, in which counterclaims may be presented which ought to have been pleaded at trial or before, is an anomalous analysis indeed. See, e.g., De Castro \& Co. v. Liberty S.S. of Panama, S.A., 186 Cal. App. 2d 628, 9 Cal. Rptr. 107 (1960).

248 A counterclaim need only "tend to diminish or defeat the plaintiff's recovery" and "exist in favor of a defendant and against a plaintiff against whom a several judgment might be had in the action." CAL. Code Crv. Proc. \& 438.

25028 Cal. 2d 627, 632, 170 P.2d 893, 897 (1946). 
waived if not seasonably pleaded. ${ }^{251}$ Not only did the Commissioner in Jones not plead payment in his answer, but he waited until the entire matter had gone to judgment and execution proceedings had begun before presenting his claim.

The rule of Jones was applied in 1950 by a district court of appeal. In Sunrise Produce Co. v. Malovich, ${ }^{252}$ plaintiff sued for goods sold and delivered; defendant admitted the account, but counterclained for trailer rentals of an agreed value exceeding plaintiff's claim. The defendant's claim was, however, ostensibly barred by the statute of limitation. The court, reversing a judgnent for the plaintiff, declined to distinguish Jones v. Mortimer and lield the defendant's claim not barred. Plaintiff in Sunrise also challenged defendant's claim that the trailer rentals had an agreed value; being unliquidated, plaintiff argued, the defendant's claim was not eligible for treatment under section 440 . The plaintiff relied on dicta in an early federal case; ${ }^{253}$ applying California law, the federal court had found it conceptually impossible that unliquidated sums could compensate liquidated sums. ${ }^{264}$ The court in Sunrise dismissed this dictum as "a little difficult to understand,"255 and said that section 440 applies to all crossdemands which satisfy the counterclaim requirement.

The Sunrise view of liquidated claims was sustained in Hauger $v$. Gates. ${ }^{256}$ Decided by the supreme court in 1954, Hauger is the third case of major siguificance im the contemporary construction of section 440 . Defendant sold plaintiff a ranch, the contract of sale providing that plaintiff be given certain ranch equipment by defendant. Defendant took a note secured by a second deed of trust as part of the consideration. Plaintiff failed to make payments on the note, claiming he need not pay until the ranch equipment was either delivered or its value received in withheld payments. The trustee recorded notice of breach; a third party with notice of plaintiff's claim bought at the sale. Seventy days later, plaintiff sued to set aside the sale. The supreme court held, taking plaintiff's allegations as true, that

plaintiffs were not in default at the time of the sale. Section 440

251 E.g., Pastene v. Pardini, 135 Cal. 431, 67 Pac. 681 (1902).

262101 Cal. App. 2d 520, 225 P.2d 975 (1950).

253 Iowa \& Cal. Land Co. v. Temescal Water Co., 95 Fed. 320 (C.C.S.D. Cal. 1899).

254 Id. at 321: "The compensation for which the section provides takes place just as soon as the cross-demands coexist; the greater demand being credited with the smaller and the latter entirely discharged. Each of the demands therefore must be of such a character that they can be mutually applied in the manner indicated. If one of them is for unliquidated damages (that is, for an uncertain amount), it is manifestly impossible for the application to take place."

255101 Cal. App. 2d 520, 525, 225 P.2d 973, 975 (1950).

25642 Cal. 2d 752, 269 P.2d 609 (1954). 
is explicit in stating that coexisting cross-demands shall be "compensated so far as they equal each other," which necessarily means that each of the claimants is paid to the extent that their claims may be balanced in amount. ${ }^{257}$

This, the court concluded, though the claim for damages for breach was unliquidated; for, as the court pointed out, "section 440 does not require that the demands be hquidated."258

Jones, Sunrise, and Hauger make section 440's breadth indisputable: all cross-demands which satisfy the counterclaim requirement are automatically extinguished to the extent they are equal at the moment they first coexist. Before attempting a critique in part VI of his Comment, it remains to discuss the scope and consequences of this interpretation, and to point out some court-made limitations upon its operation.

\section{B. Scope and Consequences of Automatic Compensation}

Other than the questions considered in Jones, Sunrise, and Hauger, namely the statute of limitation and the liquidity of the claims, problems raised by section 440 include the runming of interest on compensated demands and mutuahty.

257 Id. at 755, 269 P.2d at 610-11. California cases prior to 1927 would not have allowed Hauger to use $\S 440$ to compensate his payments on the secured note. McKean v. German-American Savings Bank, 118 Cal. 334, 50 Pac. 656 (1897), held that a bank could not invoke $\S 440$ to justify applying a customer's account to past due notes secured by mortgage. The court said that $\S 726$ of the Code of Civil Procedure prescribed the "one form of action" for recovery of a secured debt; hence, such a debt could not be set up as a counterclaim and compensation was unavailable. McKean was extended in Moore v. Gould, 151 Cal. 723, 91 Pac. 616 (1907). Moore sued to foreclose a mortgage; Gould set up simple contract debts ostensibly barred by the statute of limitation, arguing that they bad compensated the mortgage debt and could be treated as partial payments of it. (The parallel to the facts of Houger is evident.) The court held Gould's contract claims were not partial payments, for a mortgage debt could not be set up in a suit on an unsecured debt, citing $M c K e a n$, and the rights under $\$ 440$ are "necessarily mutual." The "mutuality" referred to is mutuality of remedy. See text accompanying notes 263-69 infra. But cf. McCabe v. Grey, 20 Cal. 509 (1862), allowing a mortgagor to assert as a counterclaim in a foreclosure action judgments assigned to him. $\$ 440$ was not mentioned. Cf. Williams v. Pratt, $10 \mathrm{Cal}$. App. 625, 103 Pac. 151 (1909), in which the $\$ 180$ due a Mrs. Raymond was allowed into compensation against an obligation owing on a security device in form of a deed in fee to the creditor, he giving back a contract of sale conditional upon payment of the amount owed. But the court said the device was not a mortgage.

In 1927 the legislature barred future excursions into the dialectical morass which is mutuality of remedy; it amended Code of Civil Procedure \& 438: "[T] tain a counterclaim shall not be affected by the fact that either the plaintiff's or the defendant's claim is secured by mortgage or otherwise, nor by the fact that the action is brought, or the counterclaim maintained, for the foreclosure of such security." Cal. Stats. ch. 813 (1927).

25842 Cal. 2d 752, 755, 269 P.2d 609, 611 (1954), citing Sunrise Produce Co. v. Malovich, 101 Cal. App. 2d 520, 225 P.2d 973 (1950). 


\section{Interest}

Interest does not run on a paid claim. If $A$ owes $B$ one hundred dollars at six per cent per year, and $B$ owes $A$ one hundred dollars at no interest, the claims are compensated. Should $B$ think he is accruing interest, he is mistaken. This rather straightforward deduction from the construction of section 440 announced in Jones, Sunrise and Hauger was articulated by a district court of appeal in Pan Pacific Sash and Door Co. v. Greendale Park, Inc. ${ }^{259}$ Although contrary authority exists, ${ }^{260}$ Pan Pacific reached the only result logically consistent with automatic extinction of cross-demands. ${ }^{201}$

The consequences of this cessation of interest bear pointing out. $A$ owes $B 1000$ dollars at six per cent, the interest beginning to run on January 1 . $B$ neghigently runs over $A$ with his automobile on January 1 , doing damage which a court later finds is worth 1000 dollars. Since $A$ 's and $B$ 's claims coexisted on January 1 , and since they satisfy the counterclain requirement, the adjudication of $A$ 's negligence claim amounts to a retrospective declaration that $A$ was not $B$ 's debtor as of January 1 . This has the effect of allowing $A$ interest on his tort judgment from the date of the tort, since in a state without compensatio, $A$ would get a judgment for 1000 dollars $^{262}$ and $B$ would get a countervailing judgment for 1000 dollars plus six per cent interest from January 1 . The court in such a case would set off the respective amounts as of the time of the judgment.

\section{Mutuality}

Mutuality is an omnibus term: It may denote mutuality of remedy, mutuality of obligation, or any of several other reciprocal states of bemg. In the law of compensatio, mutuality means only that, in order for compensation to take place, the demands must be due between the same parties and in the same capacity. ${ }^{263}$ This rule, first articulated by French and Roman jurists, ${ }^{264}$ means, for example, that $X$ cannot set off a personal debt against one due to himself and $Y$ as partners. Other examples commonly used by civil law writers include a father setting off debts due his

259166 Cal. App. 2d 652, 333 P.2d 802 (1958).

260 Pavlovich v. Neidhardt, 128 Cal. App. 2d 559, 275 P.2d 836 (1954), appears to be an egregious misconception of the nature of automatic compensation. Applying the rule in Pan Pacific to the facts in Pavlovich, the defendant would receive $\$ 5600$ more than the court in Pavlovich held him entitled to. At the least, the disparity illustrates that inattention to the time of accrual and extinction of the demands has serious financial results.

261 This is the result in civil law countries which have adopted automatic compensation. See text accompanying notes 46, 141, 149 sulpra. See note 179 supra.

262 Interest would run only from the date of judgment.

263 "Mutuality of remedy" is treated in note 257 supra.

264 See text accompanying note 148 supra. 
son, a husband setting off debts due the wife, and a tutor setting off debts due his pupil. In none of these cases was the required mutuality present; hence, compensatio could not take place. ${ }^{285}$

The most vexatious questions of mutuality arise today in decedent's estate hitigation. An easy case involves one who is both debtor and creditor of the estate on claims arising during its admimistration. For example, a debt owed by an executrix to the estate in the course of administration is compensated against that due her for administering the estate. ${ }^{206}$ But where one debt was incurred by the decedent during his hifetime and the other is owed to the estate, having arisen during administration, ${ }^{287}$ matters become more difficult. In one sense, mutuality is lacking: the decedent and his estate are not the same "person." 268 Yet to deny compensation in such cases does little more than promote circuity of actions and multiple payments, and the few California courts which have considered this point have relaxed the requirement of mutuality for this very reason. ${ }^{260}$

\section{Limitations Upon the Operation of Section 440}

Section 440 is not unrestrained in its operation; California courts have, in a few cases, refused to permit compensatio im the interest of some other policy or principle of law. The most important of these limitations upon section 440 are contract provisions against its use, the pohicy in favor of negotiability, the privileged character of particular demands, waiver, and estoppel.

\section{Consensual Limitation of the Right to Compensate}

A 1950 district court of appeal case ${ }^{270}$ held that a bank's right to compensate had been impliedly surrendered in a contract providing that money in a certam account was to be used to indemnify the bank against losses on paper discounted to it. This specification of a particular use and "the practice of the bank in handling the account"271 impliedly forbade

205 Pothier $\$$ 630, 632.

266 Estate of Smith, 123 Cal. App. 2d 844, 268 P.2d 53 (1954).

267 The situation could be just the reverse and the problem would be the same.

268 See People v. California Safe Deposit \& Trust Co., 168 Cal. 241, 141 Pac. 1181 (1914), discussing mutuality in exhaustive and wearisome detail.

269 People v. California Safe Deposit \& Trust Co., supra note 268; Ainsworth v. Bank of California, $119 \mathrm{Cal}$. 470, 51 Pac. 952 (1897). Allowing compensation of claims against decedents and their estates circumvents the statutory requirement that claims be presented to the executor or administrator of the estate, Cal. Prob. Code $\$ \$ 700-10$, and approved by both the representative and the probate court, Cal. Prob. Code $\S 711$. See text accompanying notes 294-96 infra.

270 Engleman v. Bank of America, 98 Cal. App. 2d 327, 219 P.2d 868 (1950). Cf. Eisendrath v. Bank of America, 118 Cal. App. 2d 434, 258 P.2d 13 (1953), in which the court construed a similar, but distinguishable, contractual arrangement to allow the bank to compensate plaintiff's account against an indebtedness.

27198 Cal. App. 2d 327, 330, 219 P.2d 868, 870 (1950). 
compensation of the account against other debts due the bank. The court's view that compensatio can be limited by an implied agreement applies $a$ fortiori to explicit consensual waiver.

\section{Negotiable Paper}

When Section 48 of the California Civil Practice Act of $1851^{272}$ was re-enacted as Code of Civil Procedure Section 440, a new sentence was added explicitly excluding from the section's operation certain crossdemands existing in favor of the maker of a negotiable instrument. ${ }^{273}$ The sentence, intended evidently to protect the negotiability of commercial paper, was deleted in the 1873-74 revision of the codes. ${ }^{274}$ Without referring to this statutory history, the supreme court in 1915 held that section 440 "was not intended to, and does not affect the negotiability of commercial paper, or the rights of bona fide transferees of such paper. ${ }^{2275}$ This rule is broader than the 1872 statutory exemption, for it covers cross-demands against, as well as in favor of, the maker of negotiable paper; the 1915 case involved a demand against the maker of a bill. Further, the court's language applies not only to makers, but to holders in due course as well.

\section{Preferred Claims}

Mechanics and former wives, inter alia, constitute groups whose interests the law is assiduous to protect. Hence, California courts have held that the obligation to pay alimony cannot be compensated against debts due the liusband from the wife, ${ }^{276}$ and that money due a general contractor, but subject to claims of subcontracting materialmen, cannot be compensated against contract damages due the owner from the general contractor. ${ }^{277}$ The husband must pay the alimony and maintaim his action for the debt. The owner must pay off the subcontractors and rely on the solvency of the general contractor, plus any sum unpaid on the contract in excess of payments to materialmen, to satisfy a damage judgment for failure to complete the contract on schedule. Similar rules might be developed with reference to other demands; for example, France excludes from compensatio the wages of a workman. ${ }^{278}$

272 Cal. Stats. ch. $5, \S 48$ (1851).

273 See text accompanying note 227 supra.

274 See text accompanying notes 229-37 supra.

$275 \mathrm{Kunz}$ v. California Trona Co., 169 Cal. 348, 146 Pac. 883 (1915).

270 Keck v. Keck, 219 Cal. 320, 26 P.2d 301 (1933). Cf. Murchison v. Murchison, 219 Cal. App. 2d 673, 33 Cal. Rptr. 285 (1963), in which compensation of a claim against the wife arising after the divorce was allowed against payments due her. Keck was distinguished on the ground that Mrs. Murchison was not receiving alimony, the payments to her being in the nature of a property settlement between the spouses.

277 Roberts v. Spires, 195 Cal. 267, 232 Pac. 710 (1925).

278 Amos \& WaLton, INTROdUction to French Law 146 (2d ed. 1963). 


\section{Waiver}

Franck v.J.J. Sugarman-Rudolph ${ }^{279}$ was a suit for the purchase price of a business which the plaintiff had sold to the defendant. Defendant asserted that the business was worth far less than the plaintiff had guaranteed it to be worth, and pleaded an agreement that plaintiff would make good any discrepancies between an audit of the business and plaintiff's representations. The court held that the defendant had waived any claim under the contract or section 440 by not responding to plaintiff's entreaties over a four-year period to deliver a copy of the audit made by defendant's accountants.

A theory similar to waiver was used in a 1922 district court of appeal case, Reveal v. Stell. ${ }^{280}$ A distributee of the estate of one Grot sued on a note made by the defendant to Grot. The defendant counterclaimed for services rendered to Grot during the latter's lifetime. The court said that the claimed compensation could not be recognized: the right to compensate cross-demands "is subject to compliance with the law requiring the presentation of such claim to the executor or administrator of the estate against which the cross-demand existed."281 A statutory claim period is, however, not unlike a statute of himitation; Jones $v$. Mortimer held that section 440 operated to discharge the mutual claims and hence that there was nothing on which the statute could run. Perhaps, therefore, Jones v. Mortimer impliedly overruled Reveal v. Stell. On the other hand, the loolding in Reveal miglit be placed upon the ground that, irrespective of whether there is a "claim upon which the statute may run,"282 the orderly administration of estates requires that all claims, compensated or not, be presented within the nonclaim period. This contention is more fully examined in the concluding section of this Comment. ${ }^{283}$

\section{Estoppel}

The supreme court applied a theory of estoppel to protect the rights of a creditor who liad sought to attach a bank deposit in Walters v. Bank of America ${ }^{284}$ Mrs. Walters served the writ on the bank in her action against Republic Securities Corporation; Republic at the time of service had a general deposit account of 8000 dollars. The bank debited the ac-

27040 Cal. 2d 81, 251 P.2d 949 (1952).

28056 Cal. App. 463, 205 Pac. 875 (1922). But cf. Loucks v. Luckel, 107 Cal. App. 2d 217, 236 P.2d 805 (1951), in which the court held that a defense of payment of a note secured by a deed of trust was not barred for failure to present it to the creditor's executor, citing § 440 .

281 Supra note 280 , at 466,205 Pac. at 876.

282 Jones v. Mortimer, 28 Cal. 2d 627, 632, 170 P.2d 893, 897 (1946).

283 See text accompanying notes 294-96 infra.

2849 Cal. 2d 46, 69 P.2d 839 (1937). 
count by this amount, applying the proceeds to a secured note of Republic's which it held, and returned the writ marked "defendant indebted to the bank. ${ }^{2285}$ Later, the bank debited the note, recredited the account, and allowed Republic to draw checks on it. Mrs. Walters had judgment agamst Republic and could not collect it; she then sued the bank, claiming to have validly attached the deposit. The court lield the bank's conduct "indisputably" inconsistent with its denial that it possessed attachable funds. ${ }^{288}$ The result seems fair, but difficult to square with section 440 as interpreted by Jones, Sunrise, and Hauger. If the note from Republic and Republic's deposit account were "cross-demands" within the meaning of section 440, they were compensated from the moment they coexisted, and there were no attachable funds in the bank's possession when Mrs. Walters' writ was served. Section 440's operation is, after all, automatic. Perhaps the result could be justified by noting that Mrs. Walters did not know Republic was indebted to the bank; as an outsider, she knew only of the deposit account. The bank was free at any time to compensate the account against the note, but did not do so until Mrs. Walters had first served her writ. Borrowing the civil law rule that compensation can never be invoked to the prejudice of third persons, ${ }^{287}$ the bank is restrained from claiming the benefit of a compensation which it did not recognize on its books until it was convenient for it to do so. But the court in Walters neither borrowed the civil law rule, nor attempted to integrate its result with any doctrinal generalities about section 440 . This omission to look beyond the facts of the case at bar to the result intended to be achieved by section 440, and to section 440's place in the substantive and adjective law of cross-demands, is characteristic of California's judicial interpretations of compensatio. The concluding section of this Comment attempts to articulate a rational policy toward section 440, in light of its history and the Califorma case law.

\section{VI \\ TOWARD A RATIONAL VIEW OF compensatio}

Admission and adjudication of cross-demands posed conceptual problems for the common law, obsessed with reducing the lawsuit to one issue and deciding it on that basis. ${ }^{288}$ The inherent pettifoggery of the writ system multiphed the difficulty. Mansfield, scliooled alike in the common

285 Id. at 50,69 P.2d at 840 .

$28 B$ Id. at 57,69 P.2d at 844 .

2875 CoNFrRence dU Code CrvnI 131 (1805).

288 "The reduction of the controversy to some specific question is the object of all pleading, and when reached, it is called the 'issue'; and the cause, when at issue, is ready or trial or for decision of the issue raised." Shrpman, Common Law Preading \& 15, at 32 (3d ed. Ballantine ed. 1923). 
and civil law, could cast aside the ideology of common law pleading; Field the reformer did the same.

But that did not of itself answer the practical problem of which crossdemands should be adjudicated in the same action. Mansfield was content to state the difficulty; Field made a small step toward meeting the problem. Today, the Federal Rules of Civil Procedure allow free joinder of counterclaims, subject to the trial court's discretion to order a separate trial. $^{288}$ The difficulty in reconciling liberal joinder with automatic compensation of cross-demands is suggested by just this provision of the Federal Rules. A judge can oversee the operation of adjective rules about cross-demands; moreover, because the whole controversy is outlined in the pleadings, all parties have notice of the claims against them. In sharp contrast, compensatio operates automatically and without notice. If plaintiff's claim has been paid by the operation of section 440 , the judge, even if he thinks proof of the cross-demand will obstruct the trial, has no power to exclude consideration of it. Section 440 is, as one court remarked, "found in a code of procedure, but it confers substantive rights."200

This should influence consideration of section 440. Competing with the policy of allowing free joinder of claims are policies which inhere in the substantive law of contracts: chiefly, the principle that men should be able to plan and order their jural relations with others, and to rely upon their plans until notified to the contrary.

Our economic system rests upon a complex network of credit transactions. Further, obhgations are freely bought and sold; one cannot be sure to whom he is indebted at any given moment. The image of the Bank of America unilaterally adjusting its books to compensate all demands against Safewray Stores suggests the difficulties posed by section 440 . But the difficulty does not, it is argued, rest with the idea of compensatio. What is unthinkable is the suggestion that the Bank might not, in the case assumed, give notice of its intention to compensate; what is unthinkable is that two mutually indebted parties should not have control over their reciprocal obligations.

In Hauger v. Gates, ${ }^{201}$ for example, the operation of compensatio seems reasonable. Why should Hauger have to sue for his ranch equipinent? Gates was not misled by the refusal to pay; he had notice of Hauger's claim and of Hauger's intention to enforce that claim by withholding payment on the note. Compensatio, it is suggested, is a beneficial and workable primciple of law; the solution to the difficulties it poses may

289 FED. R. CIV. P. 13.

200 Iowa \& Cal. Land Co. v. Temescal Water Co., 95 Fed. 320, 321 (C.C.S.D. Cal. 1899).

29142 Cal. 2d 752, 269 P.2d 609 (1954). See text accompanying notes 256-58 supra. 
be found in a more rational view of compensatio, as yet not articulated by California courts. We turn, then, to discussion of an appropriate general theory of compensatio, followed by consideration of appropriate limitations upon its operation.

\section{A. A General Theory}

The analysis of section 440 suggested here is best seen in the context of a concrete problem: the running of the statute of limitation on one of the claims. Suppose, for example, that $A$ is indebted to $B$ for one hundred dollars, and $A$ has an outstanding tort clainı against $B$ on which the statute of himitation is one year, slould $A$ 's tort claim be pleadable two years hence when $B$ sues on the debt?

Or, $A$ is indebted to $B$ in the sum of one hundred dollars, and $B$ has a similar clain against $A . B$ dies. The period for filing claims in $B$ 's estate passes, and $A$ does not file his claim. $B$ 's executor sues $A$ for the debt owed $B$. Should $A$ be able to plead compensatio?

Jones v. Mortimer ${ }^{292}$ and Sunrise Produce Co. v. Malovich ${ }^{293}$ are authority for the proposition that $A$, in both of these cases slould be able to avoid the statute of limitation or statutory clain period. Here it is argued, however, these cases are wrongly decided and that in neither of the above hypothetical cases should $A$ 's clain be admitted. Rules barring stale claims at times operate harshly, but they are essential to orderly adjudication. Estates must close, controversies must be settled or forgotten so that people can get on with their work. ${ }^{204}$ In the first case posited above, $A$ knows he has a claim against $B$; if he really wants to

29228 Cal. 2d 627, 170 P.2d 893 (1946). See text accompanying notes 247-51 supra. 293101 Cal. App. 2d 520, 225 P.2d 973 (1950). See text accompanying notes 252-55 supra.

294 Case of Broderick's Will, 21 Wall. 503, 519 (1874). The decedent was Senator Broderick, Stephen Field's friend, who was killed in a duel by Chief Justice Terry of the California Supreme Court. See Swisher, Stephen J. Fiedd: Craftsman of the Law 321-61 (1930).

The recent cases of Walker v. City of Hutchinson, 352 U.S. 112 (1956), and Mullane v. Central Hanover Bank \& Trust Co., 339 U.S. 306 (1950), cast doubt upon the traditional view that there need be little notice to found an action in rem that will be safe from collateral attack; the older cases have it that one is presumed to know if another attaches or otherwise deals with his property, or that one should be aware that one's obligor has died. But cases in which, for example, an executor knew of the decedent's obligation but failed to notify the obligee, are in principle indistinguishable from the situation in Mullone, which involved a trustee's obligation to give notice to beneficiaries of a fund comprised of many small trusts. The Court said that each case rests on its own facts: whether the given cestui has left a forwarding address, the amount of the fund and so forth. The minimum due process required, Lowever, is a letter to the cestuii's last known address. Of course, if an estate slould be reopened on due process or equitable grounds, that is a different matter. Here is argued only that the fortuitous existence of a cross-demand should not change the decision whether to reopen. 
collect it, he will see a lawyer who will tell him about the statute of limitation. The fortuitous fact of $A$ 's debt should not work a result different from that which would obtain were $A$ not $B$ 's debtor. ${ }^{205}$ In the second case, the refusal of courts to reopen probate decrees even where the claimant did not see, and could not have seen, the statutory notice, testifies to the strength of the policy in favor of settling estates quickly and finally. ${ }^{296}$

But conceptually, if compensatio be automatic and the demands paid to the extent they are equal, how can the running of the statute of limitation "unpay" them? The answer is that section 440's words do not require the view that "shall be deemed compensated" means the demands are obliterated at the moment of their coexistence. "Shall be deemed compensated" can be read to mean that the demands are provisionally linked one with another at the moment they coexist. Their actual discharge and extinction therefore, may require a further act: the statute speaks not of "compensating" but of "deeming." The further act is the assertion by one demandant of his demand, and either acquiescence by the other in the compensation or a judicial declaration that the two demands are compensated. Such an interpretation not only eliminates a conceptual obstacle to applying the statute of limitation: it better accords with the words of section 440 . To say that the demands are paid from the moment they coexist is to recast section 440 to read: "as soon as cross-demands coexist . . they shall compensate, so far as they are equal." On the other hand, to say that the demands are provisionally linked when they coexist and that some further act is necessary to bring about their extinction is to say as does section 440 that "when crossdemands have existed ... they shall be deemed compensated." The "deeming" is a facultative or vohtional act by one party or a judge, declaring the demands annihilated. It is a declaration that nothing which happened before or since the demands coexisted has operated to bar the riglit to compensatio. The "deeming" is a retrospective declaration or adjudication of payment.

205 This is not to say that other facts than $A$ 's indebtedness may not operate to vary the rule barring stale claims. For example, suppose $A$ relied upon Jones v. Mortimer, $28 \mathrm{Cal}$. 2d 627, 170 P.2d 893 (1946), and Sunrise Produce Co. v. Malovich, 101 Cal. App. 2d 520, 225 P.2d 973 (1950), discussed supra in text accompanying notes 247-55, and for that reason did not assert his claim within the limitation period. $A$ would have good ground to claim compensatio, but the substance of his claim would be that the court should do equity to his reliance-interest. A court could do this by prospectively overruling Sunrise and Jones.

296 E.g., Case of Broderick's Will, 21 Wall. 503 (1874). Granted this policy is expressed in fictions about in personam and in rem jurisdiction which, apotheosized in Pennoyer v. Neff, 95 U.S. 714 (1877), have fallen into disrepute. It is not proposed to revitalize these fictions, but to argue that the interest in winding up decedent's affairs is real and substantial. See discussion in note 295 supra. But see Loucks v. Luckel, 107 Cal. App. 2d 217, 236 P.2d 805 (1951) and notes 280 and 294 supra. 
This view accords with Pan Pacific Sash \& Door Co. v. Greendale Park, Inc., ${ }^{207}$ which held that, from the time they coexist, interest does not run on compensated demands; it also provides a consistent reference point. If $A$ and $B$ are mutually indebted, and $A$ invokes compensatio by giving notice, but $B$ refuses to accede, when does the compensatio take place? When a judge allows $A$ 's defense of compensatio in an action brought by $B$ ? When $A$ first gives notice? Or at some other time? To avoid extensive inquiries such as this, collateral to the litigation, it seems most convenient to refer to the date when the demands first coexisted. Usually that date is marked by some impressive event: for example, $A$ signed a note, or $B$ was hit by a truck. The combination of automatic extinction to stop the running of interest and volitional invocation of compensatio is a feature of Scots and German law. ${ }^{298}$ In this view, the act of $A$ or $B$ invoking compensatio, or a judge declaring it, only perfects previously-existing rights. ${ }^{209}$

If, however, neither $A$ nor $B$ assert by appropriate out-of-court conduct their rights to compensatio, the running of the statute of limitation should bar their right to assert their respective demands in a judicial proceeding. The period of tine set by the statute becomes, in this view, a practical measure of when $A$ is estopped from asserting, or has waived, his clain against $B$. Of course, if $A$ and $B$ want to agree that $A$ 's clain sliall discharge $A$ 's unbarred debt to $B$, that is their affair; but it is not a section 440 transaction.

This, then, is a suggested general theory of compensatio, consistent with the language of section 440 and the orderly adjudication of crossdemands. Given this framework, limitations upon section 440's operation, based upon familiar public policies, may be articulated.

\section{B. Limiting Section 440}

There are three principal sources of policies to himit the operation of section 440 . To begin with, courts slould consider policies which civil

297 I66 Cal. App. 2d 652, 333 P.2d 802 (1958). But see note 260 supra and accompanying text.

298 See notes 7-9 and 179 supra; BürGERLICHES GESET2BUCH \$§ 388-96.

209 Admittedly, this choice about the running of interest is somewhat arbitrary. The rational arguments for it are that it prevents a lengthy debate about who gave notice to whom and when; this debate is certain to occur if the date of notice-giving is made the date when the compensatio becomes effective. Second, the date when the demands first coexisted is in most cases relatively easy to find out. Third, the Scots, Germans and French have no difficulty with the rule suggested in the text. The inost significant argument, though, is that cessation of the running of interest at the time when the demands first coexist is consistent with the conceptual framework elaborated in part VI of this Comment; if that framework be rational and expressive of the language and intent of $\$ 440$, then the suggested provision for interest follows. 
law jurisdictions have found worthwhile, and adopt those which seem relevant. Second, unlike civil law compensatio, section 440 compasses unliquidated as well as liquidated cross-demands, and the breadth of its provisions may dictate special policies. Third, the law of contract is a source of relevant policy. The discussion can be organized under four heads: estoppel, waiver, consensual restriction of the right to compensate, and limitations arising from the nature of the demands.

\section{Estoppel}

Either of the claimants may be estopped to assert that compensatio should take place. Let us take the hypothetical which opened this Cominent: $A$ is struck by a department store delivery truck. He has a charge account at the store, on which he currently owes five liundred dollars. He decides to rely on compensatio to recompense himself for his injuries. The store sends its monthly bill, and $A$ neither pays nor explains his refusal to pay. The store sends several reminders then assigns the claim for collection. $A$ should be estopped to assert compensatio against the bill collector. His conduct led the store into thinking he would not pay, and the store expended energy and money in acting on the basis of its reasonable belief. The elements of an estoppel in pais are present.

\section{Waiver}

One who is entitled to compensatio may waive his right to it; under the analysis presented here, automatic extinction of cross-demands is not forced on a party against his will. Returning to the hypothetical concerning the department store delivery truck, the injured person has a right to compensate his claim for injury against his charge account bill. ${ }^{800} \mathrm{He}$ may, however, choose not to exercise his right; he may instead pay the bill and seek to satisfy his tort claim in some other way. This would amount to a waiver of the injured's right to compensatio. Many things could lead him to do this: for example, his tort claim may be so speculative that he does not want to jeopardize his credit rating by withholding payment on his account, and this is the probable result if a claim of compensatio later turns out to be invalid. The clearest analogy here is to a case of fraud in the inducement to contract. The aggrieved party may rescind, or he may stand on the contract and recoup his damages. If he

800 "Right" is here used in a Hohfeldian sense. To the extent, however, that compensatio is volitional, to be invoked by unilateral declaration of either of two mutual debtors, it would be more accurate to say that both debtors have a "power" to compensate. Under the analysis of $\S 440$ presented here, however, the automatic features of compensatio predominate; thus the statement that the injured in the bypothetical case has a "right" which he waives, rather than a statement that he has a "power" vihich he does not invoke. See Corbin, Legal Analysis and Terminology, 29 YALE L.J. 163, 167-69, 171-72 (1919). 
chooses to recoup by withholding payment, he must fairly estimate the damage he has suffered: if his estimate is too high, and he withholds too much, he is in default on so much of the contract price as exceeds the amount he is entitled to recoup. ${ }^{301}$ His hability-for forfeitures, default penalties, and the like-is the same as in any other case of non-payment.

The prospect of these consequences-even under California law which looks askance at forfeitures for default $\mathrm{t}^{302}$-may induce a potential claimant to pay a hquid and exigible demand against him and sue for his unhquidated claim. This should be treated as any other case of waiver..$^{303}$

\section{Consensual Restriction of Compensatio}

Engelhard v. Bank of America, ${ }^{304}$ holding that a discount agreement contained an implied term that the proceeds of notes collected were to be applied to a particular purpose, articulates another reasonable himitation upon compensatio. What may be done imphedly may also be done expressly. This is not to advocate a constructional preference for finding implied agreenients not to compensate. But where it is clear, as in Engelhard, that the parties to a contract contemplate that their respective risks of loss should be allocated in a particular way, one party should not be able to upset the arrangement by pleading compensatio. The determination will necessarily depend upon the facts of each case.

\section{Limitations Arising From the Nature of the Demands}

The civil law excepted spendthrift legacies, deposited goods, and obligations to the state from the operation of compensatio. In addition, French law provides that a worker's wages cannot be the subject of compensatio..$^{305}$ These determinations rested upon policies which the Romans, and later the French, thought important. Similarly, policies relevant today should limit the operation of section 440 .

To begin with, the civil law rule that compensatio was not available against deposited goods ${ }^{306}$ is reasonable and should be adopted by California courts. This rule would, as respects deposits of specific chattels, accord with the California Civil Code provision that, subject to a lien for storage, the depositary must return the thing deposited. ${ }^{307}$ Bentham

301 Pavlovich v. Neidhardt, 128 Cal. App. 2d 559, 561-62, 275 P.2d 836, 838 (1954).

302 See, e.g., Freedman v. The Rector, 37 Cal. 2d 16, 216 P.2d 629 (1951); Ward v. Union Bond \& Trust Co., 243 F.2d 476 (9th Cir. 1957) (applying California law).

303 For a discussion of non-volitional waiver, see text accompanying note 279 supra. 30498 Cal. App. 2d 327, 219 P.2d 868 (1950).

305 AMos \& WaIton, INTRODUCTION to FRENCH LAW 146 (2d ed. 1963).

306 Code 4.31.14; Irstriutes 4.6.30; Projet du Code Civil \$ 807 (1796); Code Civil 81293 (1804).

307 CaL. CIv. Code $\S \S 1822,1856$. 
cogently argued that the depositor may have some special attachment to a chattel which renders its value particularly dear to him. He should not be forced to liquidate his holding at its market value to transform it into money-the umiversal equivalent-in order for compensatio to take place. $^{308}$

The California cases discussed in part $\mathrm{V}$ have also recognized the special status of particular demands and refused to allow compensatio against them. Compensatio may not interfere with the negotiability of commercial paper ${ }^{309}$ Funds subject to liens may not be compensated away, leaving the lienor with a remedy beyond the property to which the lien attaches. ${ }^{310}$ Alimony cannot be "paid" merely by asserting a crossdemand and claiming compensatio. ${ }^{311}$ The policy underlying these decisions is not only that men should be able to keep what they get in good faith and for good money; the demandants comprise a class whose interests the law is assiduous to protect, and their rights should not be subject to the vagaries of fortuitously-existing cross-demands.

The civil law developed a further restriction upon compensatio which apphes specifically to banks: a bank may not take a general deposit, such as a checking account, by compensatio and apply it to a note of the depositor's. ${ }^{312}$ If compensatio is automatic, this is perhaps a good rule; if the law insisted that all reciprocal demands between, say, Safeway Stores and the Bank of America were automatically compensated the moment they coexisted, chaos would result. The parties would not be able to keep up with the bookkeeping entailed by such a rule. The theory of compensatio articulated above views compensatio differently. While under section 440, the bank has a riglit to compensate demands against Safeway in practice it seldom if ever does so. In the preceding discussion, this has been termed a waiver of the bank's right. Taking this view, chaotic consequences do not ensue because the situation is in control of the parties concerned. An objection remains, however, to allowing the bank to compensate. The bank can attacl the deposit in connection with a lawsuit, 313 or it can, without reference to section 440 , use its "banker's lien" to credit a deposit to the depositor's indebtedness. ${ }^{314}$ With this array

308 Bentraan, The Theory of Legistation 146-48 (Ogden ed. 1931).

309 Kunz v. California Trona Co., 169 Cal. 348, 146 Pac. 883 (1915). See text accompanying notes 273-75 supra.

310 Roberts v. Spires, 195 Cal. 267, 232 Pac. 710 (1925). See text accompanying note 277 supra.

311 Keck v. Keck, 219 Cal. 320, 26 P.2d 301 (1933). See text accompanying note 276 supra.

312 See Comment, 8 TUL. L. Rev. 423 (1934).

313 Cal. Code Civ. Proc. \$\$ 537-61.

314 CAL. Civ. Code $\S 3054$. See Gonsalves v. Bank of America, 16 Cal, 2d 169, 105 P.2d 118 (1940). The lien of 83054 may extend only to securities and commercial paper deposited 
of remedies, why give the bank the additional one permitted by section 440? The only reply is, why not? As construed in this Comment, there is no difference between the banker's hen and compensatio, and no net legal effect by denying the bank a remedy under section $440 .{ }^{815}$ Both means of taking a deposit should be subject to the limitations which affect all applications of section 440. Some of these are outlined above, but there are others. For example, a bank cannot assert its right to compensate a deposit and thus defeat a tax lien upon the deposit. ${ }^{316}$

Attachment raises a different set of problems. The California Code of Civil Procedure outhines a number of exemptions from attachment and execution $;^{317}$ these provisions are designed to enable a defendant or judgment debtor to continue to work and live. ${ }^{318}$ They include certain wages, ${ }^{310}$ a certain quantity of tools of one's trade, ${ }^{320}$ pensions, ${ }^{321}$ health insurance benefits, ${ }^{322}$ and so forth. When a bank is involved, these items are relevant only when they liave been converted into a deposit. But since the California rule is that at least some exempt items may be traced, giving exemption to the bank deposit into which they have been converted, ${ }^{323}$ the discussion niay be broadened to include other than banks.

by a customer of the bank. Money in a checking account, for example, becomes the property of the bank, creating the relation of debtor and creditor between customer and bank. Hence, the court in Gonsalves states that taking a customer's ordinary deposit was a nonstatutory matter governed by equitable principles of setoff. Section 440 was not mentioned.

315 This is not strictly true in all cases. Invocation by a bank of its right to compensatio is a declaration that the two demands in question were extinguished at the moment they first coexisted, and that interest did not run on either from that time. The bank's use of a setoff or banker's lien, on the other hand, is a mutual cancellation as of the time the setoff is declared; interest ceases at that moment. Where the two demands draw interest at different rates, this difference would be relevant; the difference may be nullified, though, by contract provisions respecting treatment of the demands.

316 United States v. Bank of America, 229 F. Supp. 906 (S.D.Cal. 1964). In this case, the bank asserted its right subsequent to the government's assertion of its tax lien. But where the bank knows of the financial difficulties of a customer, and within four months of his bankruptcy asserts its right to compensatio, that it would probably not be a "voidable preference" under federal bankruptcy law. See Cusick v. Second Nat. Bank, 115 F.2d 150 (D.C. Cir. 1940); 52 Stat. 878 (1938), 11 U.S.C. 108 (1958). Perhaps the difference lies in the relative strengths of the policies in favor of tax liens and in favor of the claims of creditors of the bankrupt. See text accompanying notes 163-66 supra.

317 CAT. CODE CIv. Proc. \$§ 690-90.27, 690.50-.51. Moreover, one can attach only in certain kinds of cases. See CaI. Code Crv. Proc. § 537.

318 See, e.g., In re McManus' Estate, 87 Cal. 292, 25 Pac. 413 (1890). The liberal policy of California's exemption statutes has been evidenced at least since the 1851 exemption provisions were drafted by Stephen J. Field, who describes his purpose in S. FIEID, EARLY DAXs IN CATIFORNIA 73-81, 85-89 (1880).

819 Car. Code Crv. Proc. \$§ 690.10-.11.

320 CAI. Code Civ. Proc. $\$ \$ 690.3,690.4,690.6,690.7,690.8,690.13,690.14$.

321 Cat. Code Crv. Proc. $\$ \$ 690.22-.23$.

822 Cat. Code Civ. Proc. \$ 690.20.

328 E.g., Carter v. Carter, 55 Cal. App. 2d 13, 130 P.2d 186 (1940). 
California courts should look to the attachment and execution exemption statutes for himitations upon section 440; rights which cannot be taken by attachment should not, arguably, be taken by compensatio. An employer should not be able to withhold earned wages on the ground that the employee is indebted to him; a health insurance scheme should not be able to withhold benefits to compensate debts due it by the beneficiary. To adopt the restrictions contained in the attachment and execution exemption statutes may amount to "judicial legislation," but when legislative policy is clearly expressed that certain claims are entitled to special consideration a statute may well be used as a datum for reasoning by analogy; compensatio raises problems analogous to those inherent in attachment. Due to the paucity of compensatio case law, such limitations have never been considered; and, the sweeping language of Jones, Sunrise, and Hauger portends that the policies of the attachment exemption sections would not be self-evident to California courts in litigation under section 440 .

\section{CONCLUSION}

The discussion comes to this: the experience of others demonstrates the workability of compensatio and provides suggestions for limiting its scope of operation. A few himitations derived from policies familiar to California courts could be added. The objectives are a rational basis for adjudicating cross-demands and rules sufficiently precise to enable attorneys to advise their clients intelligently. California courts should eschew judgment $a d$ hoc and begin to bring the section 440 case law into a rational pattern. In doing this, it is well to return to compensatio's origins and history in searcl of the reasons for its existence and the means to its intelligent application.

\section{Michael E. Tigart}

$\dagger$ Assistance in translating canon law materials, Beaumanoir's Coutumes de Beauvaisis, and certain German sources was given by faculty members and graduate students in Boalt Hall and the Political Science Departunent of the University of Califorma, Berkeley. Except where noted, all other translations are by the author, who is of course responsible for all errors in rendering the foreign law materials into English. 